\title{
Validation of stratospheric and mesospheric ozone observed by SMILES from International Space Station
}

\author{
Y. Kasai ${ }^{1,2}$, H. Sagawa ${ }^{1}$, D. Kreyling ${ }^{1}$, E. Dupuy ${ }^{1,3}$, P. Baron ${ }^{1}$, J. Mendrok ${ }^{4,1}$, K. Suzuki ${ }^{1,5}$, T. O. Sato ${ }^{2,1}$, \\ T. Nishibori ${ }^{6,1}$, S. Mizobuchi ${ }^{6}$, K. Kikuchi ${ }^{1}$, T. Manabe ${ }^{7}$, H. Ozeki ${ }^{8}$, T. Sugita ${ }^{4}$, M. Fujiwara ${ }^{9}$, Y. Irimajiri ${ }^{1}$, \\ K. A. Walker ${ }^{10,11}$, P. F. Bernath ${ }^{12}$, C. Boone ${ }^{11}$, G. Stiller ${ }^{13}$, T. von Clarmann ${ }^{13}$, J. Orphal ${ }^{13}$, J. Urban ${ }^{14}$, D. Murtagh Mu $^{14}$, \\ E. J. Llewellyn ${ }^{15}$, D. Degenstein ${ }^{15}$, A. E. Bourassa ${ }^{15}$, N. D. Lloyd ${ }^{15}$, L. Froidevaux ${ }^{16}$, M. Birk ${ }^{17}$, G. Wagner $^{17}$, \\ F. Schreier ${ }^{17}$, J. Xu ${ }^{17}$, P. $\operatorname{Vogt}^{17}$, T. Trautmann ${ }^{17}$, and M. Yasui ${ }^{1}$ \\ ${ }^{1}$ National Institute of Information and Communications Technology (NICT), Koganei, Tokyo, Japan \\ ${ }^{2}$ Tokyo Institute of Technology, Yokohama, Kanagawa, Japan \\ ${ }^{3}$ National Institute for Environmental Studies, Tsukuba, Ibaraki, Japan \\ ${ }^{4}$ Luleå University of Technology, Kiruna, Sweden \\ ${ }^{5}$ The University of Tokyo, Graduate School of Arts and Sciences, Meguro, Tokyo, Japan \\ ${ }^{6}$ Japan Aerospace Exploration Agency (JAXA), Tsukuba, Japan \\ ${ }^{7}$ Osaka Prefecture University, Naka, Sakai, Osaka, Japan \\ ${ }^{8}$ Toho University, Funabashi, Chiba, Japan \\ ${ }^{9}$ Hokkaido University, Kita, Sapporo, Japan \\ ${ }^{10}$ University of Toronto, Toronto, Ontario, Canada \\ ${ }^{11}$ University of Waterloo, Waterloo, Ontario, Canada \\ ${ }^{12}$ Old Dominion University, Norfolk, Virginia, USA \\ ${ }^{13}$ Institute for Meteorology and Climate Research (IMK), Karlsruhe Institute of Technology, Karlsruhe, Germany \\ ${ }^{14}$ Chalmers University of Technology, Göteborg, Sweden \\ ${ }^{15}$ Institute of Space and Atmospheric Studies, University of Saskatchewan, Saskatoon, Canada \\ ${ }^{16}$ Jet Propulsion Laboratory (JPL), California Institute of Technology, Pasadena, California, USA \\ ${ }^{17}$ German Aerospace Center (DLR), Remote Sensing Technology Institute, Oberpfaffenhofen, Weßling, Germany
}

Correspondence to: Y. Kasai (ykasai@nict.go.jp)

Received: 18 February 2013 - Published in Atmos. Meas. Tech. Discuss.: 18 March 2013

Revised: 16 July 2013 - Accepted: 23 July 2013 - Published: 10 September 2013

\begin{abstract}
We observed ozone $\left(\mathrm{O}_{3}\right)$ in the vertical region between 250 and $0.0005 \mathrm{hPa}(\sim 12-96 \mathrm{~km})$ using the Superconducting Submillimeter-Wave Limb-Emission Sounder (SMILES) on the Japanese Experiment Module (JEM) of the International Space Station (ISS) between 12 October 2009 and 21 April 2010. The new $4 \mathrm{~K}$ superconducting heterodyne receiver technology of SMILES allowed us to obtain a one order of magnitude better signal-to-noise ratio for the $\mathrm{O}_{3}$ line observation compared to past spaceborne microwave instruments. The non-sun-synchronous orbit of the ISS allowed us to observe $\mathrm{O}_{3}$ at various local times. We assessed the quality of the vertical profiles of $\mathrm{O}_{3}$ in the $100-0.001 \mathrm{hPa}$ ( 16-90 km) region for the SMILES NICT Level 2 prod-
\end{abstract}

uct version 2.1.5. The evaluation is based on four components: error analysis; internal comparisons of observations targeting three different instrumental setups for the same $\mathrm{O}_{3}$ 625.371 GHz transition; internal comparisons of two different retrieval algorithms; and external comparisons for various local times with ozonesonde, satellite and balloon observations (ENVISAT/MIPAS, SCISAT/ACE-FTS, Odin/OSIRIS, Odin/SMR, Aura/MLS, TELIS). SMILES O 3 data have an estimated absolute accuracy of better than $0.3 \mathrm{ppmv}(3 \%)$ with a vertical resolution of $3-4 \mathrm{~km}$ over the 60 to $8 \mathrm{hPa}$ range. The random error for a single measurement is better than the estimated systematic error, being less than 1,2 , and $7 \%$, in the $40-1,80-0.1$, and $100-0.004 \mathrm{hPa}$ pressure 
regions, respectively. SMILES $\mathrm{O}_{3}$ abundance was 10-20\% lower than all other satellite measurements at $8-0.1 \mathrm{hPa}$ due to an error arising from uncertainties of the tangent point information and the gain calibration for the intensity of the spectrum. SMILES $\mathrm{O}_{3}$ from observation frequency Band-B had better accuracy than that from Band-A. A two month period is required to accumulate measurements covering $24 \mathrm{~h}$ in local time of $\mathrm{O}_{3}$ profile. However such a dataset can also contain variation due to dynamical, seasonal, and latitudinal effects.

\section{Introduction}

Diurnal variations of $\mathrm{O}_{3}$ were observed from the upper troposphere up to the lower thermosphere by the Superconducting Submillimeter-Wave Limb-Emission Sounder (SMILES) from the Exposed Facility of the Japanese Experiment Module (JEM) on the International Space Station (ISS) between 12 October 2009 and 21 April 2010. The ISS has a non-sunsynchronous circular orbit at altitudes of 340-360 km with an inclination angle of $51.6^{\circ}$ to the equator, which allowed us to observe atmospheric composition at different local times.

An overview of SMILES is given in Kikuchi et al. (2010); a summary of SMILES observations for $\mathrm{O}_{3}$ and its isotopologues is given in Kasai et al. (2006), and details on the instrument and its performance are available in JEM/SMILES Mission Plan (2002). A summary of the specifications of SMILES is shown in Table 1. The SMILES instrument employed $4 \mathrm{~K}$ submillimeter-wave superconductive heterodyne receivers, and obtained spectra with unprecedented low noise, which is one order of magnitude better performance than previous microwave/submillimeter limb instruments in space.

These unique observations gave us new products, such as the diurnal variation of short-lived radical species in the stratosphere and mesosphere. SMILES observations provided vertical abundance profiles of $\mathrm{O}_{3}, \mathrm{H}^{35} \mathrm{Cl}, \mathrm{H}^{37} \mathrm{Cl}, \mathrm{ClO}$, $\mathrm{HOCl}, \mathrm{HO}_{2}, \mathrm{H}_{2} \mathrm{O}_{2}, \mathrm{BrO}, \mathrm{HNO}_{3}, \mathrm{O}_{3}$ isotopologues, $\mathrm{CH}_{3} \mathrm{CN}$, and $\mathrm{H}_{2} \mathrm{O}$, as well as ice clouds, winds, and temperature from the stratosphere to the lower thermosphere.

The JEM/SMILES mission is a joint project of the National Institute of Information and Communications Technology (NICT) and the Japan Aerospace Exploration Agency (JAXA). In this paper, we assess the $\mathrm{O}_{3}$ vertical profiles for the SMILES NICT Level-2 (L2) version 2.1.5 product, which used the version 007 calibrated Level-1b (L1b) spectra. Hereafter, we denote SMILES NICT L2 product version 2.1.5 as "SMILES". We also use "SMILES(NICT)" to denote this product when we compare to the SMILES operational L2 products, "SMILES(JAXA)". The SMILES operational products are provided by JAXA, and the owners of the operational product are both JAXA and NICT.
Table 1. SMILES specifications.

\begin{tabular}{ll}
\hline Parameters (ISS orbit) & Characteristics \\
\hline Orbit & $\begin{array}{l}\text { Inclination angle 51.6 } 6^{\circ} \\
\text { non-sun-synchronous orbit } \\
\text { with altitude } 340-360 \mathrm{~km}\end{array}$ \\
$\begin{array}{l}\text { About 91 min } \\
\text { Latit duration }\end{array}$ & $38^{\circ} \mathrm{S}-65^{\circ} \mathrm{N}$ (nominal) \\
\hline Parameters (data sampling) & Characteristics \\
\hline Measurement geometry & Limb scan \\
Scan altitude & $-20-120 \mathrm{~km}$ (geometric altitude) \\
Number of samples & $1630 \mathrm{scans}$ per day \\
Nominal data sampling & 103 scans per orbit \\
Vertical sampling interval & $0.056^{\circ}$ (about $\left.2 \mathrm{~km}\right)$ \\
\hline Parameters (instrument) & Characteristics \\
\hline Frequency range & $624.32-625.52 \mathrm{GHz}($ Band-A) \\
& $625.12-626.32 \mathrm{GHz}($ Band-B) \\
Antenna field-of-view & $649.12-650.32 \mathrm{GHz}($ Band-C) \\
Receiver system & $0.089^{\circ}$ (HPBW) $\left.\sim 3 \mathrm{~km}\right)$ \\
Spectrometers & SIS mixers and HEMT amplifiers \\
Frequency resolution & Acousto Optical Spectrometers \\
Channel separation & $1.0-1.2 \mathrm{MHz}$ \\
System noise temperature & $0.8 \mathrm{MHz}$ \\
Integration time & $315-350 \mathrm{~K}$ \\
\hline
\end{tabular}

The structure of the paper is as follows: SMILES $\mathrm{O}_{3}$ observation characteristics are shown in Sect. 2, which includes the instrumental configuration and observation sampling pattern (Sect. 2.1), the retrieval algorithm (Sect. 2.2), and $\mathrm{O}_{3}$ observation characteristics from error analysis (Sect. 2.3). The internal SMILES comparisons, Sect. 3, consists of two parts. First, in Sect. 3.1, we present the comparison of three different instrumental receiver configurations for the same $\mathrm{O}_{3}$ $625.371 \mathrm{GHz}$ transition spectral measurements to evaluate the instrumental uncertainty and characteristics. Second, in Sect. 3.2, we describe the comparison of two different retrieval algorithms applied to the same SMILES $625.371 \mathrm{GHz}$ $\mathrm{O}_{3}$ spectra. The external comparisons are shown in Sect. 4. The comparison with ozonesonde measurements is provided in Sect. 4.2; Sect. 4.3 gives the comparison with satellite observations from ENVISAT/MIPAS, SCISAT/ACE-FTS, Odin/OSIRIS, Odin/SMR, and Aura/MLS; and Sect. 4.4 shows the comparison with balloon born measurement TELIS. These observations were performed at various different local times. Finally, an example of the diurnal variation of $\mathrm{O}_{3}$ from SMILES is shown in Sect. 5. 
Table 2. Summary of the SMILES L1b products and associated L2 products. Two L2 processing chains from NICT and JAXA are denoted as SMILES(NICT) and SMILES(JAXA), respectively. The data product described in this paper is shown in bold below.

\begin{tabular}{|c|c|c|}
\hline \multicolumn{2}{|c|}{ Level-1b products } & \multirow{2}{*}{$\begin{array}{l}\text { Level-2 products } \\
\text { - SMILES(NICT) v2.0.1 } \\
\text { - SMILES(JAXA) v1.2(005-06-0032) } \\
\text { - SMILES(JAXA) v1.1(005-06-0150) }\end{array}$} \\
\hline 005 & $\begin{array}{l}\text { - Released in Nov } 2009 . \\
\text { - The first L1b product. }\end{array}$ & \\
\hline 006 & $\begin{array}{l}\text { - Released in Feb } 2011 . \\
\text { - Modification of frequency calibration algorithm for the spectrometer. } \\
\text { - Modification of ISS altitude information. } \\
\text { - Improvement of time synchronization between ISS and SMILES clocks. }\end{array}$ & $\begin{array}{l}\text { - No SMILES(NICT) product } \\
\text { - SMILES(JAXA) v1.3(006-06-0200) }\end{array}$ \\
\hline 007 & $\begin{array}{l}\text { - Released in Aug } 2011 . \\
\text { - Improvement of gain nonlinearity calibration. } \\
\text { - Improvement of AOS response functions based on on-orbit comb measurements. }\end{array}$ & $\begin{array}{l}\text { - SMILES(NICT) v2.1.5 } \\
\text { - SMILES(JAXA) v2.0(007-08-0300) })^{1} \\
\text { - SMILES(JAXA) v2.1(007-08-0310) }\end{array}$ \\
\hline 008 & $\begin{array}{l}\text { - Released in Dec } 2012 . \\
\text { - Improvement of tangent height information. } \\
\text { - Improvement of frequency calibration. } \\
\text { - Modification of gain nonlinearity calibration. }\end{array}$ & - New versions ${ }^{2}$ \\
\hline
\end{tabular}

1 There is no difference between SMILES(JAXA) v2.0 and v2.1 for the $\mathrm{O}_{3}$ product.

2 Both SMILES(NICT) and SMILES(JAXA) plan to develop new versions of their products using L1b v008.

\section{SMILES $\mathrm{O}_{3}$ characteristics: observation, retrieval, and error}

\subsection{SMILES $\mathrm{O}_{3}$ observation}

We performed the validation analysis for the main $\mathrm{O}_{3}$ $\left({ }^{16} \mathrm{O}^{16} \mathrm{O}^{16} \mathrm{O}\right)$ observation at the transition frequency $625.371 \mathrm{GHz}$ for $\left(J, K_{a}, K_{c}\right)=(15,6,10)-(15,5,11)$, while SMILES observed other kinds of $\mathrm{O}_{3}$, such as $\mathrm{O}_{3}$ isotopologues (asym-17- $\mathrm{O}_{3}$, asym-18- $\mathrm{O}_{3}$, sym-17- $\mathrm{O}_{3}$, sym$18-\mathrm{O}_{3}$ ) and several vibrationally excited state $\mathrm{O}_{3}$ transitions. Details of the SMILES $\mathrm{O}_{3}$ observations are shown in Kasai et al. (2006).

SMILES has three different instrument (receiver) configurations for observing the $625.371 \mathrm{GHz} \mathrm{O}_{3}$ transition. One of the purposes for this was to evaluate the characteristics of the receiver systems by comparing results from the same $625.371 \mathrm{GHz} \mathrm{O} 3$ observation. The targeted $625.371 \mathrm{GHz} \mathrm{O}_{3}$ transition is allocated in two frequency regions Band-A (624.32-625.52 GHz) and Band-B (625.12626.32 GHz). SMILES employed two Acousto Optical Spectrometers (AOSs) with a bandwidth of $1.2 \mathrm{GHz}$, which are denoted as AOS1 and AOS2 in this paper. The combinations of the two frequency bands (A and $\mathrm{B}$ ) and two spectrometers (AOS1 and AOS2) resulted in three different instrumental setups for the $625.371 \mathrm{GHz} \mathrm{O}$ measurements; that is, (1) Band-A with AOS1, (2) Band-A with AOS2, and (3) Band-B with AOS2. The Band-B observation was always performed with the spectrometer AOS2. During each measurement, two out of the three SMILES frequency bands were observed simultaneously, i.e., $\mathrm{A}+\mathrm{B}, \mathrm{C}+\mathrm{B}$, and $\mathrm{C}+\mathrm{A}$. We do not use Band-C $(649.12-650.32 \mathrm{GHz})$ to retrieve the $\mathrm{O}_{3}$ vertical profile.
Figure 1 shows the number of SMILES $\mathrm{O}_{3}$ observations for each day of the mission by $5^{\circ}$ latitude bins. For several specific periods, the ISS rotated $180^{\circ}$ around its yaw axis, and thus the observation latitude range was shifted to southern high latitudes. Relatively high sampling density is shown at both ends of the latitudinal range where the orbit changes from the ascending to descending phase. In each orbit there was a period when the ISS solar array wing (solar paddle) disturbed the observation line-of-sight (LOS) of SMILES, which rendered the observed data useless. This decreases the sampling density as shown by the dark blue $\mathrm{X}$ shapes in Fig. 1. The decrease in number of measurement was typically $4.5-8.4 \%$ (of the daily 1630 scans) during October 2009 to April 2010; however, in December 2009 the measurement decreased by $48 \%$.

\section{2 $\mathrm{SMILES} \mathrm{O}_{3}$ retrieval procedure}

Vertical profiles of the $\mathrm{O}_{3}$ volume mixing ratio (VMR) for SMILES v2.1.5 are derived from the L1b version 007 calibrated spectra. A summary of the SMILES L1b products and associated L2 products are shown in Table 2.

The retrieval algorithm is based on the least-squares method with a priori constraint (e.g., Rodgers, 2000). Detailed algorithm description for the version 2.0.1 series of the SMILES NICT L2 processing can be found in Baron et al. (2011). Briefly, the forward model consists of a clear-sky radiative transfer model and the numerical instrument functions of SMILES. For submillimeter-wave limb observations from space, continuum absorptions due to $\mathrm{H}_{2} \mathrm{O}$ and dry air become one of the dominant opacity sources in the lower stratosphere. The SMILES continuum absorptions model was made based on a model described in Pardo et al. (2001). 


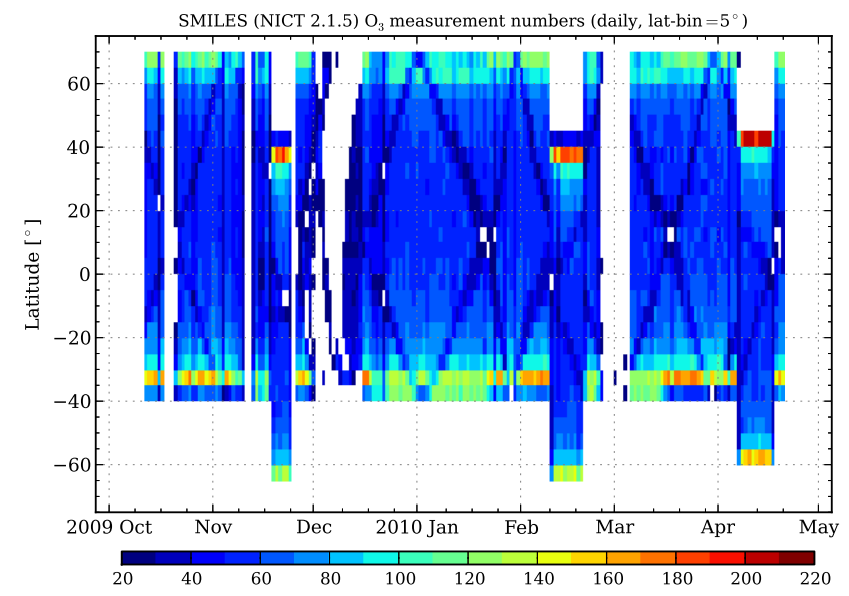

Fig. 1. Number of $\mathrm{O}_{3}$ observations (scans) of the SMILES (NICT) v2.1.5 product. The data are accumulated in daily, $5^{\circ}$ wide latitudinal bins. Measurements from both Band-A and Band-B are merged.

The dry air continuum absorption coefficient was increased by a factor of $20 \%$ from the original formula, in order to give a better agreement with the theoretical models (e.g., Boissoles et al., 2003) in the SMILES frequency range.

The version 2.0.1 series of the NICT L2 processing focuses on analysis in the middle stratosphere and the mesosphere. We used the $\mathrm{O}_{3}$ spectra with only $570 \mathrm{MHz}$ bandwidth, in the frequency region of $625.042-625.612 \mathrm{GHz}$, instead of using the full $1.2 \mathrm{GHz}$ bandwidth of the AOS in order to obtain a better fit of the spectral baseline and to stabilize the retrieval procedure. Such a reduction in the spectral bandwidth results in the removal of information coming from the wing of the $\mathrm{O}_{3}$ line, and thus it degrades the sensitivity to $\mathrm{O}_{3}$ at lower altitudes such as the upper troposphere.

First of all, we performed the correction of the tangent height information before retrieving all other Jacobians such as $\mathrm{O}_{3}$ profiles. The LOS elevation angles (i.e., tangent heights of the limb measurements) were corrected for each spectrum by deriving the information from the pressureinduced spectral linewidth of the $\mathrm{O}_{3}$ line. The performance of LOS elevation angle retrieval using the $\mathrm{O}_{3}$ transition is discussed in Baron et al. (2011).

Second, the $\mathrm{O}_{3}$ profiles were retrieved including following parameters as additional variables: temperature, $\mathrm{HCl}, \mathrm{HNO}_{3}$, $\mathrm{HOCl}, \mathrm{H}_{2} \mathrm{O}$, and a linear baseline of the spectrum. An offset for the LOS elevation angle was again set as a variable at this step in order to obtain a better fit on the measurement. We used a priori information for $\mathrm{O}_{3}, \mathrm{H}_{2} \mathrm{O}$, temperature, and pressure from the analysis of the Goddard Earth Observing System Model version 5.2 (GEOS-5.2) (Rienecker et al., 2008). The inversion grid is 3 and $4 \mathrm{~km}$-steps for $16.5-61.5 \mathrm{~km}$, and $65-81 \mathrm{~km}$, respectively, with additional 86,92 , and $100 \mathrm{~km}$ levels.
Figure 2 shows an example of the SMILES $\mathrm{O}_{3}$ retrieval. The version 2.1.5 of NICT L2 processing uses the SMILES measurements for which tangent heights are within 15$110 \mathrm{~km}$, and three of them are shown in the plot as examples. The retrieved $\mathrm{O}_{3}$ profile from this single scan measurement is shown in the middle panel with information on the $1 \sigma$ retrieval error and vertical resolution. Averaging kernels (right panel in Fig. 2) describe the sensitivity of the retrieved $\mathrm{O}_{3}$ abundance to the true state. Their vertical spread is used as an indication of the vertical resolution of the retrievals. It is $3-4 \mathrm{~km}, 4-6 \mathrm{~km}$, and $6-10 \mathrm{~km}$ at $50-0.2 \mathrm{hPa}, 0.2-0.02 \mathrm{hPa}$ and $0.02-0.001 \mathrm{hPa}$, respectively.

The measurement response is the sum of the elements of each averaging kernel row, where low values indicate high contributions from the a priori state to the retrieved information. We assessed the quality of retrieval by using the following quantities: goodness of the fit based on the chi-square statistics $\chi^{2}$ after the retrieval, averaging kernels, and the $m$ : measurement response (Rodgers, 2000). The $\chi^{2}$ used in the SMILES NICT processing is the summation of the squared and variance weighted residuals in the measurement space and the null space after they are normalized by the number of measurements and retrieval parameters (see Eq. 2 given by Baron et al., 2011). A typical $\chi^{2}$ of the SMILES v2.1.5 $\mathrm{O}_{3}$ product is $0.6-0.8$; being smaller than unity is because of the overestimation of the measurement noise (Baron et al., 2011). Hereafter, we consider $\chi^{2} \leq 0.8$ as the data selection threshold to remove bad-fitted scans. The condition for $m$ is also set to be larger than 0.8 . This gives the sensitivity range of the SMILES $\mathrm{O}_{3}$ from a single scan as $100-0.001 \mathrm{hPa}$ $(\sim 16-90 \mathrm{~km})$.

\subsection{Error analysis of SMILES $\mathrm{O}_{3}$ vertical profile}

Two components are important to explaining the SMILES systematic error: one is the uncertainty in the forward model parameterization, and the other is the uncertainty of the calibration of L1b spectra. We estimated such systematic errors for the single scan profiles by the perturbation method (Rodgers, 2000; Kasai et al., 2006; Baron et al., 2011), which takes the difference of two $\mathrm{O}_{3}$ profiles that are retrieved from two different cases of the simulated spectra: ones simulated with a perturbed forward model and the other ones with the original forward model used in the SMILES v2.1.5 processing. The measurements were simulated using the Band-B characteristics with five randomly selected $\mathrm{O}_{3}$ reference profiles from the GEOS-5.2 data for the equatorial daytime conditions.

The error sources and their perturbation parameters are summarized in Table 3. The uncertainty in the spectroscopic parameters includes the target $\mathrm{O}_{3}$ line and also other species. The uncertainty related to the SMILES instrument functions is given by the SMILES instrument team, for example, Ochiai et al. (2012), Mizobuchi et al. (2012) and Sato et al. (2012). 

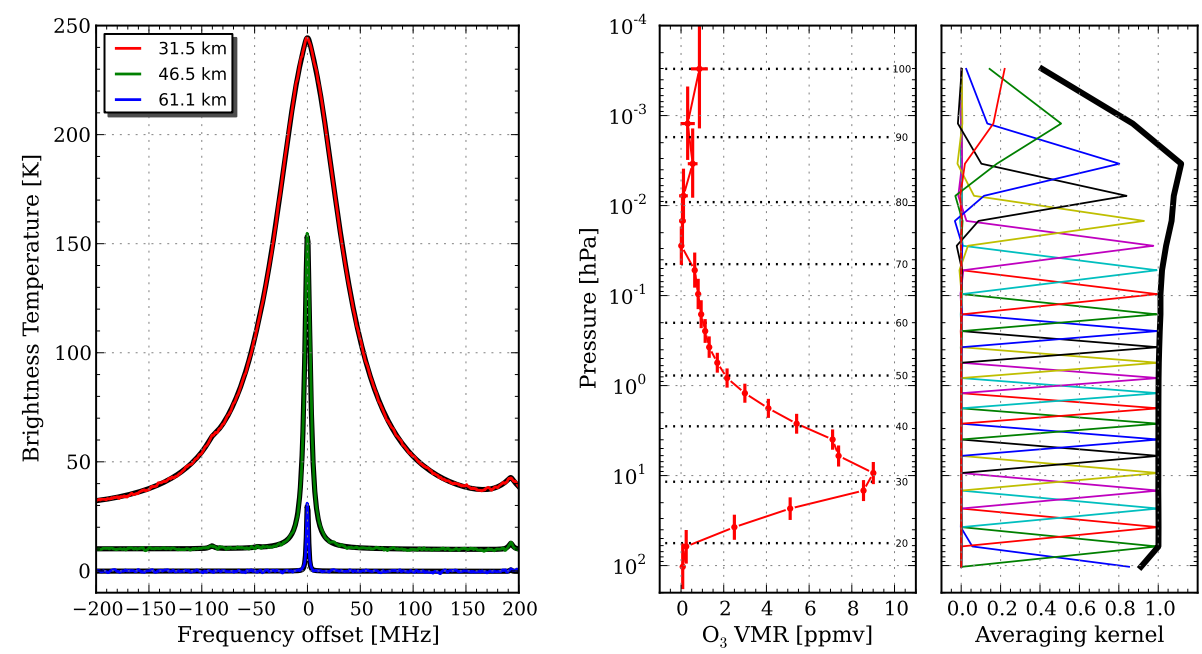

Fig. 2. An example of $\mathrm{O}_{3}$ retrieval from a single-scan measurement. Left panel shows the measured spectra from tangent heights of 31.5 , 46.5 , and $61.1 \mathrm{~km}$, and the fitted synthesis spectrum (gray line behind the red, green blue lines). An offset of 10 and $20 \mathrm{~K}$ is added for the two higher tangent height spectra, respectively. Middle panel shows the retrieved $\mathrm{O}_{3}$ profile with vertical and horizontal bars indicating the vertical resolution and $1 \sigma$ retrieval error (sum of the measurement and smoothing errors). The small numbers at the right represent the corresponding altitude in $\mathrm{km}$. Right panel shows the averaging kernels of the retrieval (colored lines) and the measurement response (thick black line).

The NICT v2.1.5 processing uses simplified instrumental functions regarding the antenna field-of-view (FOV) drift during data integration of one spectrum at each tangent point $(0.47 \mathrm{~s})$ and the effect from the image side-band signal. The SMILES antenna FOV drifts about a half of its half-powerbeam-width (HPBW) beam size during $0.47 \mathrm{~s}$; however, the forward model assumes an antenna response pattern with an instantaneous single-FOV pointing at each tangent height for the observed spectra. This makes an underestimation of the HPBW of the effective antenna response pattern. For the image side-band signal treatment, the NICT v2.1.5 processing did not take this into account because its impact was thought to be negligible for the main target vertical ranges.

The error from the uncertainty of the registered tangent height information is not included as an explicit error source in the presented error analysis because these are retrieved in the processing. However, since the $\mathrm{O}_{3}$ retrieval was carried out based on this retrieved tangent height information, errors on the $\mathrm{O}_{3}$ retrieval can be introduced if any errors exist in the tangent height retrievals. Such an error propagation is considered in our error analysis simulations.

Figure 3 shows the estimated systematic errors for the NICT v2.1.5 $\mathrm{O}_{3}$ retrieval. The same analysis for the BandA configuration was performed and we got almost the same results as Band-B. Total systematic error, labeled as "RSS_total" in Fig. 3, was calculated as a root-sum-square (rss) of all the considered error factors. The negative sign means that the v2.1.5 processing underestimated the $\mathrm{O}_{3}$ profile. On the plot, only the error sources with an impact larger than $5 \%$ of the total rss error are shown (which confirms that the image side-band signal can be neglected in the stratosphere). The largest error source is the air pressure broadening coefficient ("o3g") followed by its temperature dependence ("o3n") and the antenna FOV drift treatment ("antscan"). The uncertainty on the air pressure broadening coefficient can bias the $\mathrm{O}_{3}$ retrieval by more than $5 \%$ in the stratosphere. The nonlinearity in the gain correction ("cal2") was estimated by assuming $20 \%$ uncertainty in the gain compression factor, yielding an error of $0.1 \mathrm{ppmv}(\sim 1.8 \%)$ in the stratosphere. The total systematic error was estimated to be about $3-8 \%$ in the stratosphere with this being $3.8 \%$ at the peak of the $\mathrm{O}_{3}$ profile. It should be noted that we estimated the errors for only the direct effects on $\mathrm{O}_{3}$ spectrum and profiles, and did not estimate the second-order effects, such as an error of temperature profile.

For the mesosphere (pressure $\leq \sim 0.2 \mathrm{hPa}$ ), the uncertainty in the AOS response function becomes one of the dominant sources of the systematic error $(5-10 \%)$. This is because the $\mathrm{O}_{3}$ linewidth becomes comparable or narrower than the FWHM (Full Width Half Maximum) of the AOS response function. For comparison, the measurement noise $\left(\mathrm{O}_{3}\right.$ error due to statistical noises of the SMILES measurement) and the smoothing error (error introduced in the inversion analysis) from a single scan are also shown in the Fig. 4. These two errors can be considered as the random error of the $\mathrm{O}_{3}$ profile, and are much smaller than the systematic error in the stratosphere. The measurement noise error is kept very low compared to the systematic errors, even smaller than $1 \%$ of the retrieved $\mathrm{O}_{3}$ profile, at $50-1 \mathrm{hPa}$. This emphasizes the importance of understanding the systematic error budget of the $\mathrm{SMILES}_{3}$ product. For the upper mesosphere the random error dominates the total error budget, which implies 


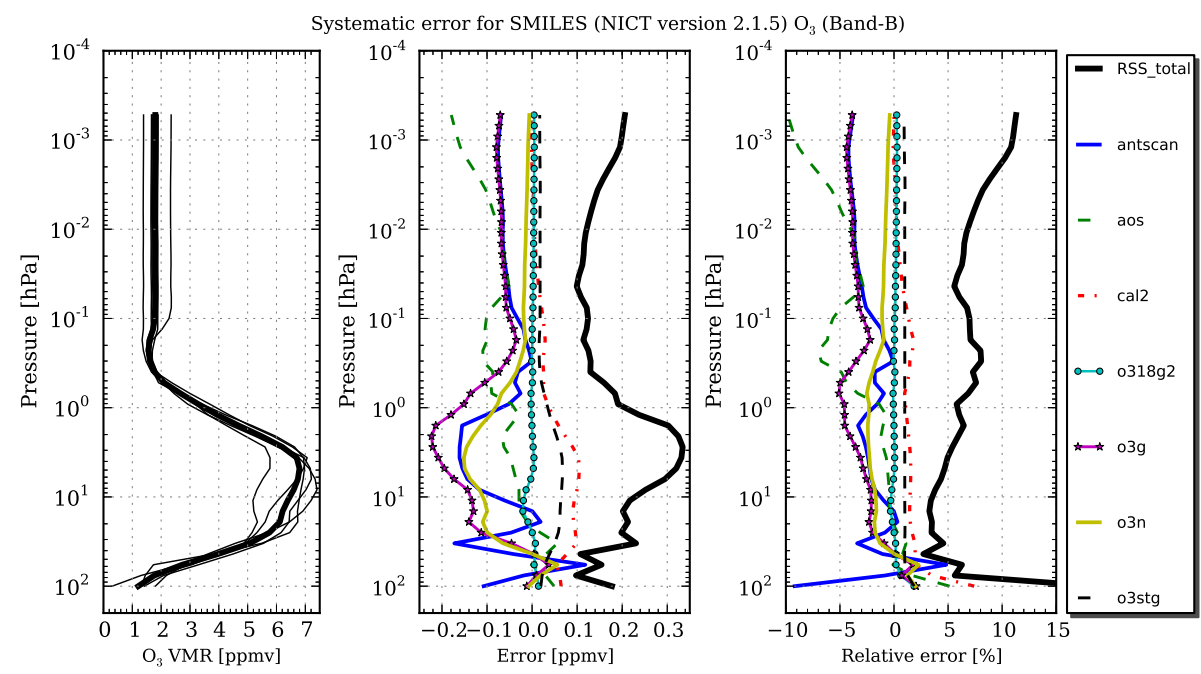

Fig. 3. Estimated systematic errors for an $\mathrm{O}_{3}$ (Band-B) profile from the NICT Level-2 v2.1.5. Left panel shows the reference $\mathrm{O}_{3}$ profiles used for the error estimation. Center and right panels show the estimated error in $\mathrm{O}_{3}$ retrieval with absolute and relative values, respectively. In these panels, the thick black line represents the total systematic error calculated with the root-sum-square of the individual error sources. Other notations are the error from the uncertainty of antscan: the antenna FOV drift; aos: the AOS spectrometer; cal2: nonlinearity gain correction; $0318 \mathrm{~g} 2$ : the pressure broadening parameter $\gamma$ of asym-18- $\mathrm{O}_{3}$ at $625.563 \mathrm{GHz}$; o3g: the pressure broadening parameter $\gamma$ of $\mathrm{O}_{3}$; $\mathrm{o} 3 \mathrm{n}$ : the temperature dependence of $\gamma$ of $\mathrm{O}_{3}$; and o3stg: the line intensity of $\mathrm{O}_{3}$. Also see Table 3 for the assumed uncertainties on these error sources. The errors from the uncertainties of the image side-band, dry continuum, and other spectroscopic parameters are not shown in here because of their relatively small impacts.

that averaging of profiles is required to obtain an improved signal-to-noise ratio.

\section{Internal comparisons within various $\mathrm{SMILES} \mathrm{O}_{3}$ products}

\subsection{Comparison between two different observational configurations}

As described in Sect. 2.1, SMILES has three configurations for observing the $\mathrm{O}_{3} 625.371 \mathrm{GHz}$ transition. The observation configuration set of Band-A (AOS1) + Band-B (AOS2) (denoted as $\mathrm{A}+\mathrm{B}$ mode hereafter) measured the same spectrum within the same air mass with nearly the same instrumental front-end characteristics (antenna characteristics, antenna scanning pattern, the optical characteristics). Comparing the $\mathrm{O}_{3}$ profiles retrieved from the two bands under the $\mathrm{A}+\mathrm{B}$ configuration helps in assessing the difference of the instrumental characteristics of each receiver and the spectrometer, which are the most important instrumental characteristics for estimating the gain calibration accuracy.

Figure 5 shows the difference between the calibrated radiances of the Band-A (AOS1) and Band-B (AOS2) spectra during the SMILES observation period. The residual clearly shows the variations along the observation period as shown in the bottom panel of Fig. 5. The brightness temperature difference was small in October 2009 (daily average of the rms (root mean square) difference was as small as $0.3 \mathrm{~K}$ ), and sharply increased in December (average rms was $\sim 0.8 \mathrm{~K}$ ). Such characteristics may be explained by the change of the AOS operational configuration: the thermal control system of the AOS spectrometers was switched off at the end of October 2009 for a longer lifetime. The gain calibration of the SMILES L1b radiance spectra version 007 uses the calibration parameters based on the observations performed early October 2009. It is likely that the change in the AOS characteristics before and after thermal control was switched off introduced a significant change in the parameters for the nonlinearity gain calibration. This issue will be investigated in the future using the next version of the L1b data in which it is planned to implement nonlinearity gain calibration parameters evaluated with consideration of the different conditions of the AOS thermal control.

Figure 6 shows the comparison between $\mathrm{O}_{3}$ profiles observed with Band-A (AOS1) and Band-B (AOS2) using the $\mathrm{A}+\mathrm{B}$ measurements. The data are from the latitudinal range $30^{\circ} \mathrm{S}-30^{\circ} \mathrm{N}$ in December 2009. The center and right panels show the mean of the absolute and relative differences, respectively. Note the relative difference is defined as the ratio to the reference $\mathrm{O}_{3}$ profile, which is the mean of two compared profiles. In this subsection we focus on the results for SMILES(NICT) profiles, and the results for SMILES(JAXA) will be discussed in Sect. 3.2.

The $\mathrm{O}_{3}$ VMRs of SMILES(NICT) Band-A are significantly $(\sim 0.4 \mathrm{ppmv}$, or $5 \%$ at $8.3 \mathrm{hPa}$ level $)$ larger than those of Band-B. In the error analysis presented in Sect. 2.3, we do not find any error source which can reproduce such 
Table 3. Systematic errors and their perturbations considered in this study. For each error source, the corresponding label in Fig. 3 is indicated in the parentheses. The resulting error values at the $\mathrm{O}_{3}$ peak level $(8.3 \mathrm{hPa}$ or $36 \mathrm{~km})$ are given in the right column.

\begin{tabular}{|c|c|c|}
\hline Error source & Perturbation & $\begin{array}{r}\text { Error on } \mathrm{O}_{3} \\
\text { at } 8.3 \mathrm{hPa}\end{array}$ \\
\hline \multicolumn{3}{|l|}{ Spectroscopic parameters of $\mathrm{O}_{3} 625.371 \mathrm{GHz}$} \\
\hline Line intensity $(\mathrm{O} 3 \mathrm{stg})$ & $1 \%$ & $1.0 \%$ \\
\hline Air pressure broadening, $\gamma(\mathrm{O} 3 \mathrm{~g})$ & $3 \%$ & $-2.2 \%$ \\
\hline Temperature dependence, $n$, of $\mathrm{O} 3 \mathrm{~g}(\mathrm{O} 3 \mathrm{n})$ & $10 \%$ & $-1.8 \%$ \\
\hline \multicolumn{3}{|l|}{ Impact from other species } \\
\hline $\mathrm{H}^{35} \mathrm{Cl}-625.901 \mathrm{GHz} \gamma(\mathrm{HCl} 35 \mathrm{~g})$ & $3 \%$ & $0.01 \%$ \\
\hline $\mathrm{H}^{35} \mathrm{Cl}-625.901 \mathrm{GHz} n(\mathrm{HCl} 35 \mathrm{n})$ & $10 \%$ & $0.01 \%$ \\
\hline $\mathrm{H}^{37} \mathrm{Cl}-624.964 \mathrm{GHz} \gamma(\mathrm{HCl} 37 \mathrm{~g})$ & $3 \%$ & $0.02 \%$ \\
\hline $\mathrm{H}^{37} \mathrm{Cl}-624.964 \mathrm{GHz} n(\mathrm{HCl} 37 \mathrm{n})$ & $10 \%$ & $0.01 \%$ \\
\hline $\mathrm{O}_{3} \mathrm{v}_{1,3}-625.051 \mathrm{GHz} \gamma(\mathrm{O} 3 \mathrm{v} 13 \mathrm{~g})$ & $3 \%$ & $0.01 \%$ \\
\hline $\mathrm{OO}^{18} \mathrm{O}-625.091 \mathrm{GHz} \gamma(\mathrm{O} 318 \mathrm{~g})$ & $3 \%$ & $0.01 \%$ \\
\hline $\mathrm{OO}^{18} \mathrm{O}-625.563 \mathrm{GHz} \gamma(\mathrm{O} 318 \mathrm{~g} 2)$ & $3 \%$ & $-0.2 \%$ \\
\hline Dry air continuum (DRY) & $20 \%$ & $-0.05 \%$ \\
\hline \multicolumn{3}{|l|}{ Instrumental functions } \\
\hline Image side-band (SSB) & See below ${ }^{1}$ & $-0.08 \%$ \\
\hline AOS response function width (AOS) & $10 \%{ }^{2}$ & $-0.4 \%$ \\
\hline Antenna FOV drift (ANTSCAN) & See below ${ }^{3}$ & $-1.8 \%$ \\
\hline \multicolumn{3}{|l|}{ Calibration } \\
\hline Nonlinearity gain correction (CAL2) & $20 \% 4$ & $1.5 \%$ \\
\hline Total (RSS_total) & & $3.8 \%$ \\
\hline \multicolumn{2}{|c|}{$\begin{array}{l}\text { Difference between the cases considering the realistic rejection rate for the image } \\
\text { ide-band signal and an ideal one. } \\
\text { Perturbation added on the FWHM of the response function. }\end{array}$} & $\begin{array}{l}r \text { the image } \\
\text { the antenna }\end{array}$ \\
\hline
\end{tabular}
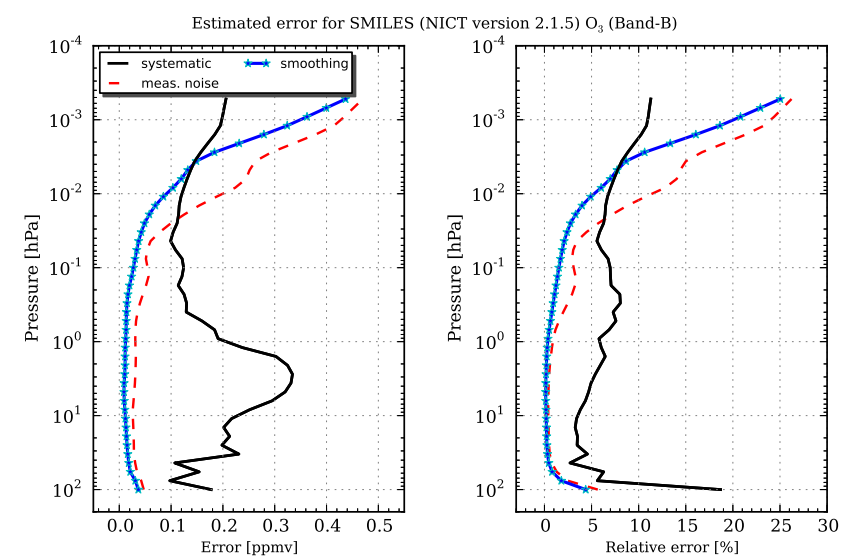

Fig. 4. Estimated systematic and random errors due to the model parameters and calibration error for the SMILES O $\mathrm{O}_{3}$ (Band-B) profile. Total systematic error is shown in a black profile. The red dashed profile represents the measurement noise error for a single scan, and the blue line with star symbols is the smoothing error. Total systematic error is from Fig. 3.
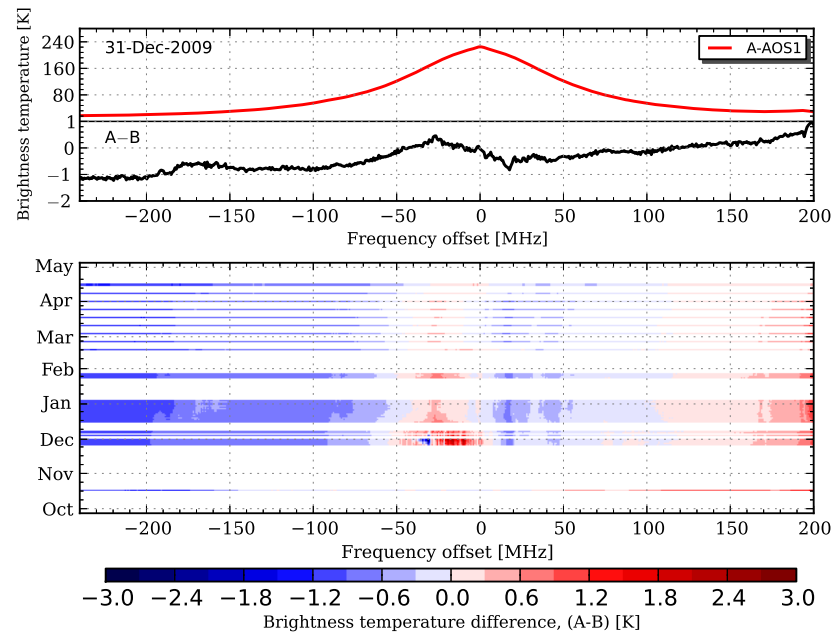

Fig. 5. Difference between the calibrated $\mathrm{O}_{3}$ spectra of Band-A and Band-B from the SMILES L1b version 007. Top panel shows an averaged radiance over ten spectra for a tangent height around $30 \mathrm{~km}$ observed with Band-A, and the difference from that of Band$\mathrm{B}$ (an average of ten differences calculated from each A-B pair). Ten scans were selected from the equatorial region measurements $\left(30^{\circ} \mathrm{S}-30^{\circ} \mathrm{N}\right)$ on 31 December 2009 . The horizontal axis is the frequency offset from $625.371 \mathrm{GHz}$. Bottom panel contour plot represents the temporal change of the radiance difference around the tangent height of $30 \mathrm{~km}$. The blank region in the lower panel is the dates when SMILES was not operated in the A + B configuration.

significant differences between Band-A and Band-B processing. This indicates that there are unimplemented error sources (or imperfect modeling of gain calibration uncertainty) in our analysis and/or the considered perturbation was underestimated. We consider that the actual difference between Band-A and Band- $\mathrm{B}_{3}$ profiles is most likely due to the gain calibration uncertainty of the L1b spectrum being amplified by the LOS elevation angles (tangent heights) correction procedure of SMILES(NICT) processing. The LOS elevation angles retrieved from the coincident Band-A and Band-B measurements differ by $\sim 0.006^{\circ}(300 \mathrm{~m})$ for tangent heights around $30-35 \mathrm{~km}$. This $300 \mathrm{~m}$ error propagates in the $\mathrm{O}_{3}$ VMR retrieval which uses again the L1b spectrum with gain calibration errors, and finally results in such significant VMR differences between the $\mathrm{O}_{3}$ profiles from Band-A and Band-B. This issue will be further discussed in Sect. 3.2.2 by comparing the Band-A-Band-B discrepancies of NICT and JAXA L2 processings.

The seasonal and latitudinal changes in the differences between SMILES(NICT) v2.1.5 $\mathrm{O}_{3}$ profiles from Band-A and Band-B are shown in Fig. 7. The A-B difference in the $\mathrm{O}_{3}$ profiles at $8.3 \mathrm{hPa}$ is very small in October 2009 . This is consistent with the difference in the L1b spectral radiance shown in Fig. 5. Some of the seasonal behavior of the $\mathrm{O}_{3}$ Band$\mathrm{A}$ and Band-B difference, such as a large change during December 2009, follows the trend in the system noise tempera- 


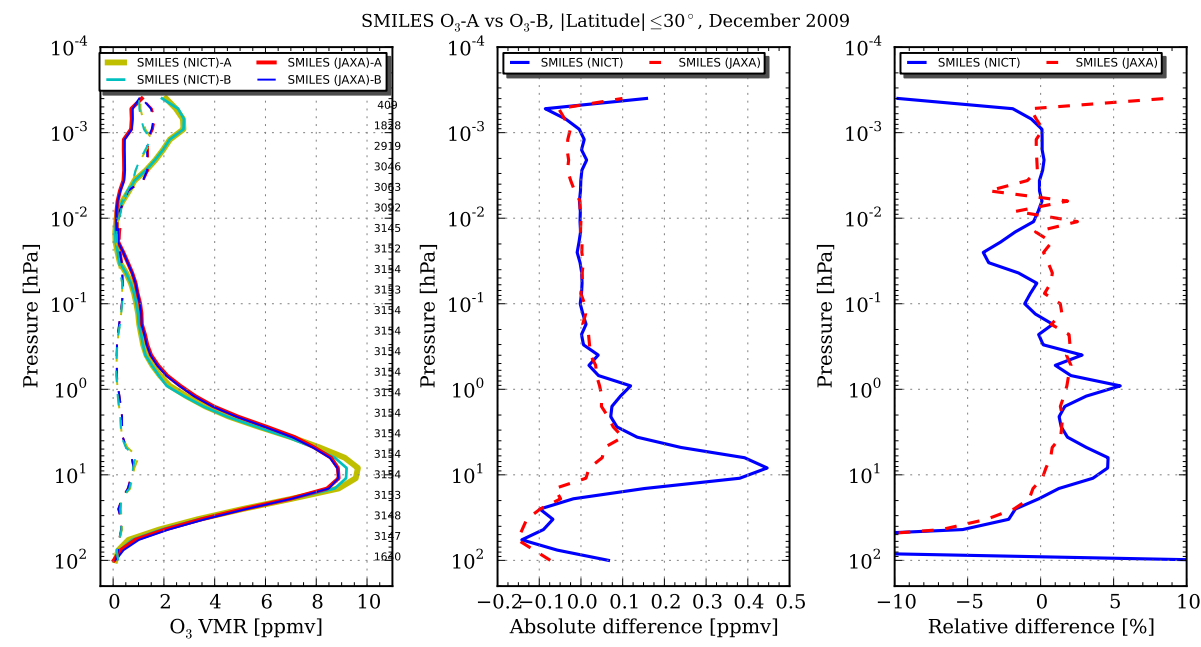

Fig. 6. Comparison of $\mathrm{O}_{3}$ profiles retrieved from Band-A and Band-B when these frequency bands were operated simultaneously (December 2009). Left panel shows the mean VMR profiles (solid) for $\mathrm{O}_{3}$ from Band-A and Band-B processed by the SMILES(NICT) and SMILES(JAXA) L2 chains. Dashed profiles represent the standard deviation of each dataset. Small numbers on the right of the panel are the number of data points used in the averaging. Center and right panels are the absolute and relative differences of $\mathrm{O}_{3}$ retrieved from Band-A and Band-B for SMILES(NICT) and SMILES(JAXA) products, respectively.

ture of the SMILES instrument. This suggests that the instrumental characteristics have no small effect on the observed difference in $\mathrm{O}_{3}$. Interestingly, the difference in the $\mathrm{O}_{3}$ profiles becomes smaller when SMILES was in the Southern Hemisphere observation mode, which is not consistent with the trend of the system noise temperature. Further investigations regarding to the sensitivity of $\mathrm{O}_{3}$ retrieval to the instrumental characteristics are now under way using the newly calibrated L1b spectra 008 .

\subsection{Comparison with JAXA-processed SMILES $\mathrm{O}_{3}$ profiles}

\subsubsection{Major differences in the $\mathrm{O}_{3}$ retrieval algorithms}

We performed a comparison of the NICT-processed SMILES $\mathrm{v} 2.1 .5 \mathrm{O}_{3}$ profiles with those retrieved by the JAXA L2 processing version 2.0 (007-08-0300). These two L2 data products are denoted as SMILES(NICT) and SMILES(JAXA), respectively, in this section.

Both L2 products are retrieved from the same version of the SMILES spectra (L1b 007), use the same principal retrieval algorithm (i.e., the least-squares method with regularization based on a priori constraints), and use the same instrumental functions in the forward model except for the antenna FOV drift and image side-band signal treatments (as discussed in Sect. 2.3). The major differences in these processors which have the possibility of causing significant impacts on $\mathrm{O}_{3}$ retrieval results for SMILES(NICT) and SMILES(JAXA) are as follows:

1. Forward model radiative transfer:
- $\mathrm{O}_{3}$ spectroscopic parameters: the two L2 processings use the almost same parameters for the $\gamma\left(2.31 \mathrm{MHzhPa}^{-1}\right)$ of the $\mathrm{O}_{3}$ line, but the temperature dependence $(n)$ of the $\gamma$ is different. SMILES(NICT) and SMILES(JAXA) used 0.73 (based on the parameter used in the Aura/MLS data processing) and 0.78 (based on the HITRAN 2008 database, Rothman et al., 2009), respectively.

- Continuum model in the submillimeter-wave region: SMILES(NICT) uses the continuum model based on the work by Pardo et al. (2001) with an empirical scaling as described in Sect. 2.2, while SMILES(JAXA) uses the Liebe-93 model (Liebe et al., 1993) with a scaling factor of 1.34 .

2. Forward model instrumental function:

- Drift of SMILES antenna FOV: the SMILES(NICT) takes a single instantaneous FOV pointing at each tangent height, whereas the SMILES(JAXA) uses a more realistic antenna pattern by convolving the drift of the antenna FOV during the data integration of a spectrum at one tangent height.

3. Retrieval setups:

- Inversion approach and the spectral bandwidth used in the retrieval: the SMILES(NICT) v2.1.5 processor is based on a sequential inversion approach for each major retrieval parameter. It first retrieves the tangent height information and 
then $\mathrm{O}_{3}$ and temperature. Both retrieval steps for the tangent heights and $\mathrm{O}_{3}$ VMRs employ a $570 \mathrm{MHz}$ bandwidth spectral region centered at $625.371 \mathrm{GHz}$. The SMILES(JAXA) processor uses the full spectral range of AOS bandwidth, $1.2 \mathrm{GHz}$, and retrieves all physical parameters simultaneously.

- Tangent height retrieval: SMILES(NICT) retrieves the LOS elevation angles for each tangent height of the limb scan measurement and corrects them prior to the $\mathrm{O}_{3}$ retrieval, while SMILES(JAXA) retrieves a single offset parameter for the LOS elevation angle.

- Temperature a priori and its retrieval: a priori temperature and pressure profiles used in the SMILES(NICT) processor are based on the GEOS-5.2 analysis and MSIS climatology data. In the SMILES(JAXA) processing they are based on the GEOS-5.2 and MLS version 2.2 data product and include the effect of migrating tides. Both the SMILES(NICT) and the SMILES(JAXA) processors regard the temperature profile as a retrieval parameter but in a different way. The SMILES(JAXA) v2.0 processor imposes a very strict a priori constraint above $40 \mathrm{~km}$ which does not allow noticeable deviations of the retrieval from the a priori profile at these high altitudes, and no retrieved information comes for the temperature profile. Thus the temperature information for SMILES(JAXA) becomes identical to that of the a priori profile at those high altitudes. However, the SMILES(NICT) processor retrieves the temperature profile simultaneously with a $\mathrm{O}_{3}$ VMR profile.

- Hydrostatic equilibrium condition: SMILES(JAXA) processor uses the hydrostatic equilibrium condition to correct the pressure profile every time after the temperature profile is retrieved. In contrast, the SMILES(NICT) processing does not employ the hydrostatic equilibrium condition. The reason for this is to avoid propagation of errors originating in the temperature retrieval. As shown in Baron et al. (2011), retrieving the tangent heights independently and representing the retrieved VMR profiles on pressure levels significantly reduced the impacts of the pressure errors on the $\mathrm{O}_{3}$ retrieval.

- A priori profiles and vertical correlations for $\mathrm{O}_{3}$ : SMILES(NICT) uses a priori information based on the GEOS-5.2 analysis with a $3 \mathrm{~km}$ correlation length in the vertical grid, while SMILES(JAXA) uses data from the monthly, latitudinally and
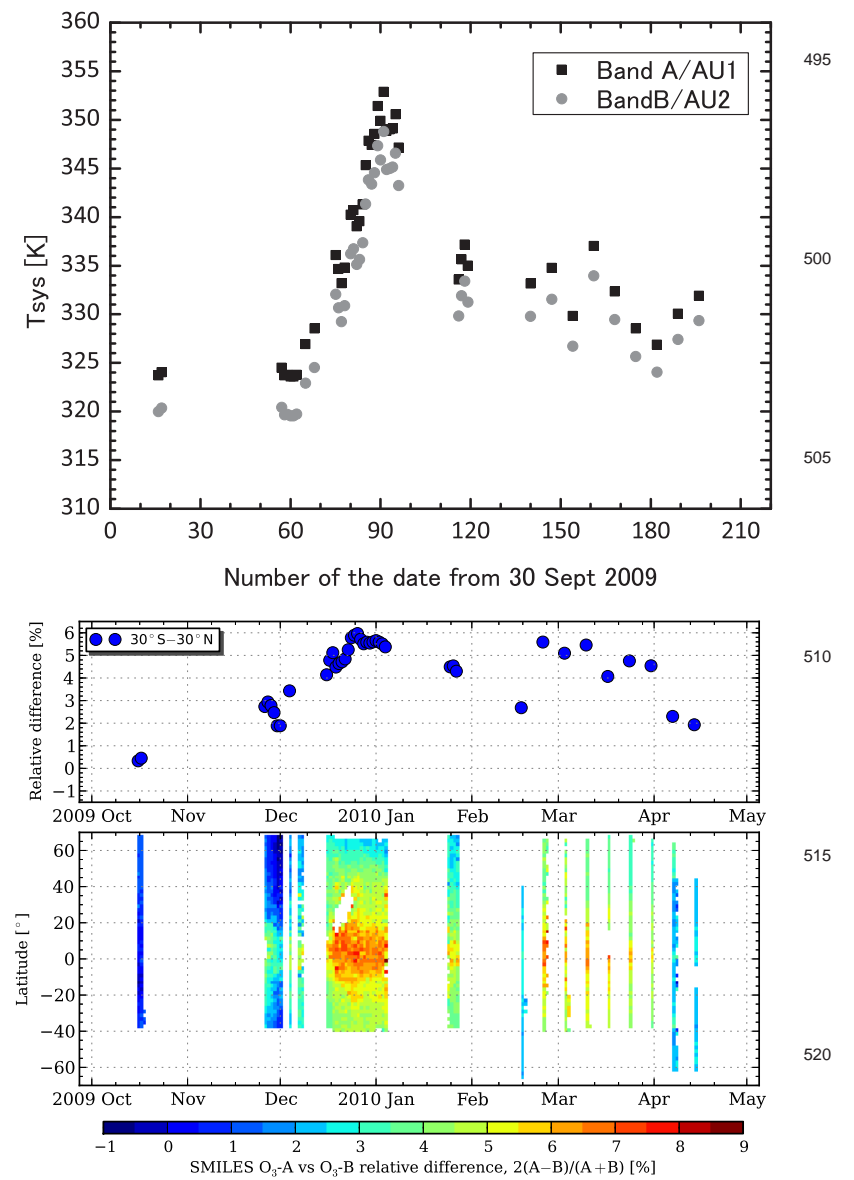

Fig. 7. Upper panel: the day-to-day variation of the system temperature of the receiver (Tsys). Tsys of the Band-A with AOS unit 1 (AU1) and the Band-B with AOS unit 2 (AU2) are shown respectively. Tsys here is the daily average of band-averaged receiver output. Calibration data in the tropical observation scans are averaged. Middle panel: the daily mean difference in the tropics $\left(30^{\circ} \mathrm{S}-30^{\circ} \mathrm{N}\right)$. Lower panel: seasonal and latitudinal variation of the SMILES $\mathrm{O}_{3}$ Band-A and Band-B difference at $8.31 \mathrm{hPa}$. Only the dates when the measurement numbers are larger than 50 are shown. The blank regions in the lower panel are the dates when SMILES was not operated in the $\mathrm{A}+\mathrm{B}$ configuration.

day-night separately averaged MLS v2.2 product with near-zero correlations.

\subsubsection{Comparison of the SMILES(NICT) and the SMILES(JAXA) $\mathrm{O}_{3}$ profiles}

As shown in Fig. 6, both SMILES(NICT) and SMILES(JAXA) $\mathrm{O}_{3}$ profiles have discrepancies between those retrieved from the coincident measurements of Band-A and Band-B. The A-B discrepancy in the SMILES(JAXA) $\mathrm{O}_{3}$ is smaller than that in SMILES(NICT), but still not negligible.

In the differences found between SMILES(NICT) and SMILES(JAXA) profiles, the negative values below the $\mathrm{O}_{3}$ 

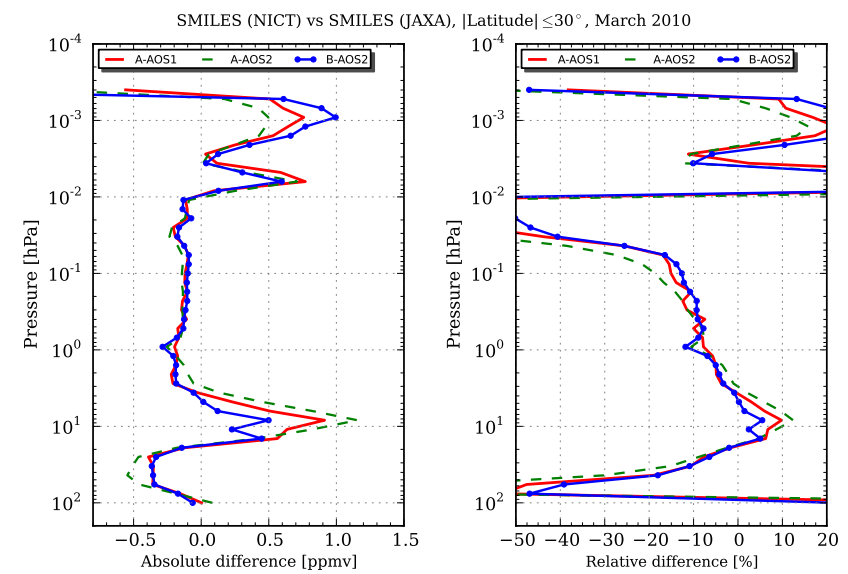

Fig. 8. Difference profiles of $\mathrm{O}_{3}$ : SMILES(NICT)-SMILES(JAXA) for each band and AOS configuration, from March 2010 observations. Absolute and relative differences are shown in the left and right panels, respectively.

peak $(\sim 10 \mathrm{hPa})$ and the positive values above indicate a significant error due to a bias from the tangent height retrieval. When the LOS elevation angle correction of SMILES(NICT) retrieval is turned off before $\mathrm{O}_{3}$ retrieval, the Band-A-Band$\mathrm{B}$ discrepancy on SMILES(NICT) $\mathrm{O}_{3}$ was same as that of SMILES(JAXA) as shown in Fig. 6. This means that the SMILES(NICT) $\mathrm{O}_{3}$ retrieval algorithm enhanced the error on $\mathrm{O}_{3}$ retrieval (at maximum $5 \%$ in the stratospheric region) through its way of applying the tangent height correction. The root cause of such an error amplification is considered to be the uncertainty in the gain calibration. This BandA-Band-B difference is expected to be reduced in the next version of the SMILES(NICT) L2 product by using the improved gain calibration L1b spectra (version 008).

We performed the SMILES(NICT)-SMILES(JAXA) comparisons for three instrumental subsets: (1) $\mathrm{O}_{3}$ observed in Band-A with AOS1 (2) Band-A with AOS2, and (3) Band$B$ with AOS2, in order to examine the effects of the different radiometer bands and different spectrometers, separately.

Figure 8 shows the mean absolute and relative differences in absolute and relative amplitudes between the SMILES(NICT) and SMILES(JAXA) $\mathrm{O}_{3}$ profiles for the three instrumental configurations. The data were collected from the March 2010 observations at the equatorial region $\left(30^{\circ} \mathrm{S}-30^{\circ} \mathrm{N}\right)$. The number of scans used for the comparisons was $\sim 2000, \sim 5200$, and $\sim 7900$ for the cases (1), (2), and (3), respectively.

The overall trends in the differences between the SMILES(NICT) and SMILES(JAXA) $\mathrm{O}_{3}$ products were the same for three instrumental subsets. As shown in Fig. 3, the difference at the $\mathrm{O}_{3}$ maximum is sensitive to the differences of the antenna drifting model and the pressure broadening parameter. The systematic bias between 2 and $0.01 \mathrm{hPa}$, where SMILES(NICT) shows smaller VMRs than those of
SMILES(JAXA), is quite likely explained to be due to the difference in the tangent height corrections of both retrieval algorithms. The oscillation in the difference in the middle/upper mesosphere is considered to be due to several reasons including the difference in the temperature profile and tangent height correction. The large difference below $20 \mathrm{hPa}$ is considered to be due to the difference in the spectral bandwidth used in the retrieval and the submillimeter-wave continuum model.

Looking into the details of band and AOS dependencies of the $\mathrm{O}_{3}$ differences in Fig. 8, the largest difference could be found for the case of Band-A with AOS2 (i.e., when SMILES observed $\mathrm{O}_{3}$ with the Band-C $+\mathrm{A}$ configuration). The relative difference is $12 \%$ at $8.3 \mathrm{hPa}$. When Band-A is used with AOS1 (A + B configuration), the difference became slightly smaller $(10 \%)$ at $10 \mathrm{hPa}$ than that of the $\mathrm{C}+\mathrm{A}$ case. The Band-B (always observed with the AOS2) $\mathrm{O}_{3}$ has the best agreement between the SMILES(NICT) and SMILES(JAXA) products around $10 \mathrm{hPa}$, although it still differs by $\sim 5 \%$. Considering that the SMILES(NICT)SMILES(JAXA) difference is strongly affected by the gain calibration errors, our comparisons suggest that the gain calibration accuracy seems to be better for Band-B. A small impact of the AOS is found for the Band-A retrievals in the stratosphere.

We investigated the impact of the different approaches for the tangent height correction and the hydrostatic equilibrium constraint between SMILES(NICT) and SMILES(JAXA). Figure 9 shows the change in the SMILES(NICT)SMILES(JAXA) difference when we turned off the tangent height correction before the $\mathrm{O}_{3}$ retrieval, and also including the hydrostatic equilibrium condition in the SMILES(NICT) processing. Without the tangent height correction, the altitude where the maximum SMILES(NICT)SMILES(JAXA) difference exists becomes slightly higher at $\sim 3-5 \mathrm{hPa}$, which corresponds to the steepest slope in $\mathrm{O}_{3}$ VMR profile. The difference then goes to zero around the $1 \mathrm{hPa}$ level, and at the altitudes higher than $0.5 \mathrm{hPa}$ the new SMILES(NICT) profile shows larger $\mathrm{O}_{3}$ VMRs than SMILES(JAXA), which is the opposite trend to that shown in the original SMILES(NICT)-SMILES(JAXA) compositions. When we applied the hydrostatic equilibrium condition, the discrepancy between the SMILES(NICT) and the SMILES(JAXA) $\mathrm{O}_{3}$ profiles increased in the mesosphere (pressures lower than $1 \mathrm{hPa}$ ). This demonstrates that the difference in the temperature profile amplifies the difference in $\mathrm{O}_{3}$ retrieval through the application of the hydrostatic equilibrium: differences in the temperature profile induce differences in the pressure profile, and then propagate to the differences in $\mathrm{O}_{3}$ VMR. The SMILES(NICT) v2.1.5 processor does not employ the hydrostatic equilibrium constraint in order to avoid such error amplifications.

Finally, the seasonal and latitudinal changes in the SMILES(NICT)-SMILES(JAXA) difference are shown in Fig. 10. The top panel shows the seasonal evolution of the 

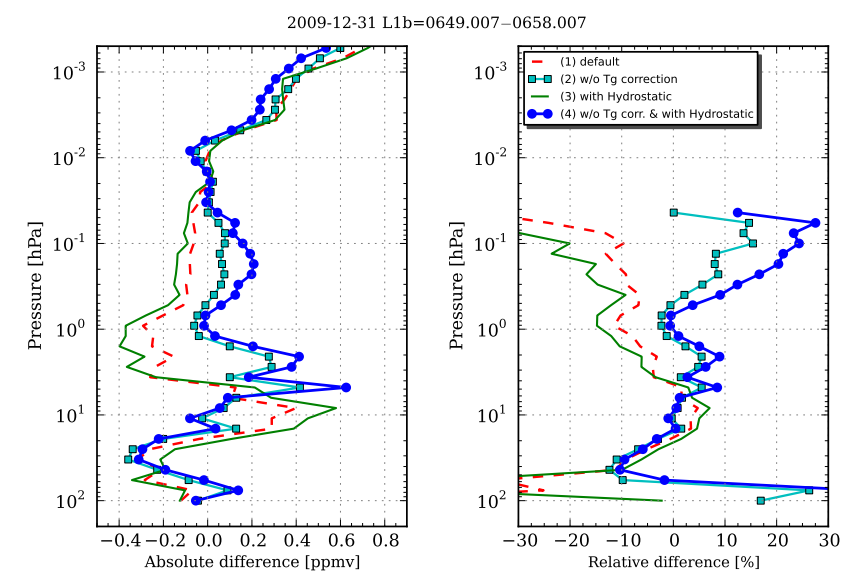

Fig. 9. Difference in the $\mathrm{O}_{3}$ profiles retrieved in the SMILES(NICT) and SMILES(JAXA) processing when changing the tangent height correction method and adding the hydrostatic equilibrium condition for the SMILES(NICT) processing. Analysis of ten BandB scans from 31 December 2009 were averaged. The original SMILES(NICT)-SMILES(JAXA) $\mathrm{O}_{3}$ difference is shown in the red dashed curve as reference. The cases for the SMILES(NICT) processing without the tangent height correction, and with the hydrostatic equilibrium condition are shown in the cyan profile with square symbols and the green solid profile, respectively. The blue profile with dot symbols represents the case with no tangent height correction and with the hydrostatic equilibrium condition included.

daily averaged differences at $8.3 \mathrm{hPa}$ from the equatorial region. The SMILES(NICT)-SMILES(JAXA) difference for the Band- $\mathrm{B} \mathrm{O}_{3}$ retrieval stayed relatively small compared to the Band-A products during the entire SMILES observation period. In the Sect. 3, we noted that the Band-A and Band-B difference for the SMILES(NICT) product is smaller when ISS rotated $180^{\circ}$ (Fig. 7). The latitudinal variation resembles the pattern of the previously shown inter-band difference of Band-A and Band-B that has a larger discrepancy at the equatorial latitudes.

\section{External comparisons}

\subsection{Methodology of comparisons}

The comparison of the two $\mathrm{O}_{3}$ profile datasets were performed by finding pairs of the coincident measurements, using a methodology which is based on the works by Dupuy et al. (2009), von Clarmann (2006), and Chauhan et al. (2009). We set a horizontal distance of within $300 \mathrm{~km}$ on the measurement location as a criteria for selecting a pair of coincident measurements between SMILES and other satellite/balloon-borne instruments. A $3 \mathrm{~h}$ threshold for the measurement time difference was also applied except for the comparisons with the ACE-FTS and ozonesonde measure-

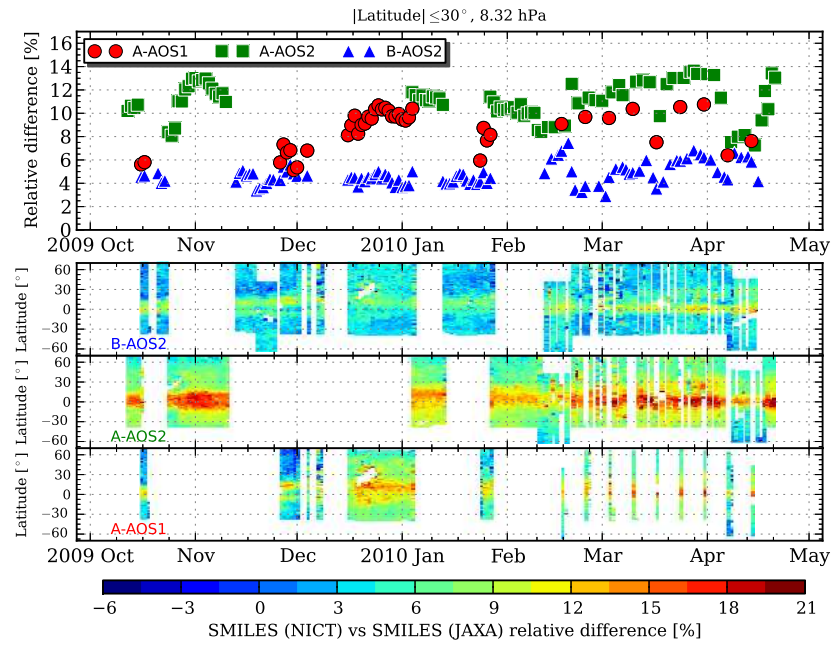

Fig. 10. Seasonal and latitudinal variation of $\mathrm{O}_{3}$ differences between SMILES(NICT) and SMILES(JAXA) shown in the same figure format as Fig. 7.

ments, for which a $12 \mathrm{~h}$ criteria was used because of their more sparse measurements.

The data quality selection criteria for the SMILES dataset was as follows:

- the measurement response $(m) \geq 0.8$, and

- the goodness of fit $\left(\chi^{2}\right) \leq 0.8$.

The $\chi^{2}$ and $m$ were applied for the retrieved ozone abundance at the every tangent height of one scan retrieval scheme. A total of $90 \%$ of the data was left after the flaggings. We also applied a certain data quality selection for the compared instruments based on the recommendation from each data processing team. A summary of the coincidences for each comparison dataset is given in Table 4.

The ozonesonde measurements have a vertical resolution of about $50-100 \mathrm{~m}$. The vertical resolutions for the satellite measurements are about $1.0-2.0 \mathrm{~km}, 2.5-6.0 \mathrm{~km}, 2.7-3 \mathrm{~km}$, 3-4 km for OSIRIS, MIPAS, SMR (Jégou et al., 2008), MLS (Froidevaux et al., 2008), and ACE-FTS, respectively. Direct comparisons are applied for MLS, SMR, MIPAS, and ACEFTS since the vertical resolutions and sampling intervals are comparable with that of SMILES. We applied a vertically smoothing triangle function as shown in Eq. (1), using the width of SMILES averaging kernel, for the ozonesonde and Odin/OSIRIS datasets.

The smoothing function is

$$
x^{\text {smooth }}\left(p_{i}\right)=\frac{\sum_{j=1}^{n_{i}} w_{j}\left(p_{j}^{\mathrm{raw}}-p_{i}\right) \cdot x^{\mathrm{raw}}\left(p_{j}^{\mathrm{raw}}\right)}{\sum_{j=1}^{n_{i}} w_{j}\left(p_{j}^{\mathrm{raw}}-p_{i}\right)},
$$

where $x^{\text {smooth }}\left(p_{i}\right)$ is the smoothed volume mixing ratio for the high-vertical resolution measurement at pressure $p_{i}, x^{\text {raw }}$ is the original VMR of the high-resolution profile, $w_{j}$ is 
the associated weight (function of $p_{j}^{\text {raw }}-p_{i}$ ), and $n_{i}$ is the number of grid points from the high-resolution measurements which exist within the SMILES vertical resolutionwidth layer centered at $p_{i}$. Once the vertical resolutions are adjusted, we interpolated the $\mathrm{O}_{3}$ VMR profiles into a reference vertical grid which was generated on a pressure coordinate with intervals of $\sim 3 \mathrm{~km}$. The interpolation of VMRs was done by using a linear interpolation with respect to the logarithm of the pressure levels.

The mean absolute difference, $\Delta_{\text {abs }}$, at the pressure level, $p$, between the coincident $\mathrm{O}_{3}$ profiles was calculated using

$\Delta_{\mathrm{abs}}(p)=\frac{1}{N(p)} \sum_{i=1}^{N(p)}\left\{x_{s}(p)-x_{c}(p)\right\}$,

where $N(p)$ is the number of coincidences at $p$, and $x_{s}(p)$ and $x_{c}(p)$ are the VMRs at $p$ for SMILES and the comparison instrument, respectively. The mean relative difference in percent was calculated by using the mean of two $\mathrm{O}_{3}$ profiles as a reference,

$\Delta_{\text {rel }}(p)=\frac{1}{N(p)} \sum_{i=1}^{N(p)} \frac{x_{s}(p)-x_{c}(p)}{\bar{x}(p)} \times 100$,

where the reference $(\bar{x}(p))$ is

$\bar{x}(p)=\frac{1}{2}\left(x_{s}(p)+x_{c}(p)\right)$

except for the comparison with ozonesonde. The reference for the ozonesonde comparison was set as equal to the ozonesonde measurement, i.e., $\bar{x}=x_{\text {sonde. }}$ This is because we consider that below $30 \mathrm{~km}$ the ozonesonde measurement technique is more reliable than that of SMILES (or any satellite-based remote sensing).

\subsection{Ozonesonde}

An ozonesonde is a balloon-borne instrument measuring the atmosphere in situ from the ground to $\sim 35 \mathrm{~km}$, where the balloon bursts. They are launched from each ozonesonde station about once a week and measure the profile of $\mathrm{O}_{3}$, total pressure, temperature, and humidity. The vertical resolution of an ozonesonde profile is about $50-100 \mathrm{~m}$.

We used the ozonesonde data available from the World Ozone and Ultraviolet Data Center (WOUDC) (http:// www.woudc.org/) and the Southern Hemisphere Additional Ozonesondes (SHADOZ) project (http://croc.gsfc.nasa.gov/ shadoz/) (Thompson et al., 2003) for the dates from 12 October 2009 to 21 April 2010. We used the data from three types of ozonesonde instruments: the carbon-iodine ozonesonde (CI) (Kobayashi and Toyama, 1966), Brewer-Mast (BM), (Brewer and Milford, 1960), and the electrochemical concentration cell (ECC) (Komhyr et al., 1995). These instruments have basically the same principle, which is to measure $\mathrm{O}_{3}$ by using an electrochemical reaction cell containing a cathode (made of platinum) and an anode (made of platinum, silver or activated carbon) in a solution of potassium iodide (KI) (Kerr et al., 1994). According to Harris et al. (1998), the precisions of the three ozonesonde types are within $\pm 3 \%$, while systematic biases compared to other $\mathrm{O}_{3}$ sensing techniques are smaller than $\pm 5 \%$ between the tropopause and $\sim 28 \mathrm{~km}$. Above $28 \mathrm{~km}$, precision depends on the type of ozonesonde. For example, the bias is $-15 \%$ at $30 \mathrm{~km}$ for the BM ozonesonde and $\pm 5 \%$ for the ECC one. In addition, the precision for the ECC ozonesonde depends on the manufacturer and the concentration of the solution of KI. For example, an ozonesonde with $1.0 \% \mathrm{KI}$ solution and a full buffer has a $5 \%$ larger $\mathrm{O}_{3}$ VMR than that with $0.5 \%$ $\mathrm{KI}$ and a half buffer, and has a $10 \%$ larger one than that with $2.0 \% \mathrm{KI}$ and no buffer (Smit et al., 2007). With the criteria of $\pm 12 \mathrm{~h}$ and $\pm 300 \mathrm{~km}, 159$ and 133 coincidences were found for the comparison between SMILES Band-A and Band-B, as shown in Table 4. The ozonesonde stations where the coincidences were found are listed in Table 5 and plotted in Fig. 11.

The results are shown in Fig. 12. Two SMILES observation bands were treated separately. The plot shows -7 to $+8 \%$ relative differences $(-0.3-+0.5 \mathrm{ppmv}$ in absolute differences) between SMILES and ozonesondes in the pressure range between 40 and $8 \mathrm{hPa}(\sim 22$ to $32 \mathrm{~km})$. The difference is larger for Band-A compared to that of Band-B, which suggests the accuracy of the SMILES $\mathrm{O}_{3}$ profile is better for the Band-B product than that for the Band-A. The difference became larger with decreasing altitude. In the upper troposphere (e.g., pressures higher than $60 \mathrm{hPa}$ ), the SMILES $\mathrm{O}_{3}$ product VMRs were smaller than ozonesonde measurements by $-20 \%$. According to the averaging kernels of the retrieval, it is supposed that the SMILES $\mathrm{O}_{3}$ profiles still have sensitivity at pressure levels as high as $100 \mathrm{hPa}$ (see Fig. 2). The accuracy of the SMILES product at this upper tropospheric region will be improved for the next version of NICT L2 processing.

\subsection{Satellite-borne instruments}

We performed the comparisons with Aura/MLS, SCISAT/ACE-FTS, ENVISAT/MIPAS, Odin/OSIRIS, and Odin/SMR, which observe $\mathrm{O}_{3}$ at various local times as shown in Table 4.

\subsubsection{Aura/MLS}

The Aura satellite was launched on 15 July 2004 into a sunsynchronous orbit at $705 \mathrm{~km}$ altitude, with an ascending equator crossing time of 13:45 (Schoeberl et al., 2006). Its orbit is near-polar with a $98^{\circ}$ inclination, and the daily Microwave Limb Sounder (MLS) measurements cover the latitudinal range from about $82^{\circ} \mathrm{S}$ to $82^{\circ} \mathrm{N}$. MLS measures temperature and trace gas profiles $\left(\mathrm{O}_{3}, \mathrm{H}_{2} \mathrm{O}, \mathrm{HNO}_{3}, \mathrm{HCl}\right.$, etc.) using thermal emission data (day and night scans) from the upper troposphere to the mesosphere. MLS performs each 
Table 4. Summary of the comparison datasets and the coincidences criteria applied in this study. Local time of the equator crossing is shown for satellites with a sun-synchronous orbit.

\begin{tabular}{|c|c|c|c|c|c|c|c|c|}
\hline \multirow[t]{2}{*}{ Instruments } & \multirow{2}{*}{$\begin{array}{l}\text { Equator } \\
\text { crossing }\end{array}$} & \multirow{2}{*}{$\begin{array}{l}\text { Data } \\
\text { version }\end{array}$} & \multirow{2}{*}{$\begin{array}{c}\text { SMILES } \\
\text { Band }\end{array}$} & \multirow{2}{*}{$\begin{array}{l}\text { Latitude } \\
\text { range }\end{array}$} & \multirow{2}{*}{$\begin{array}{c}\text { No. of } \\
\text { coincidences }\end{array}$} & \multicolumn{2}{|c|}{ Criteria } & \multirow{2}{*}{$\begin{array}{l}\text { Obs. altitude range } \\
\text { and retrieval grid }\end{array}$} \\
\hline & & & & & & {$[\mathrm{h}]$} & {$[\mathrm{km}]$} & \\
\hline \multirow[t]{2}{*}{ Aura/MLS } & 1:45 a.m./ & \multirow[t]{2}{*}{3.30} & A & $70^{\circ} \mathrm{S}-68^{\circ} \mathrm{N}$ & 20583 & \multirow[t]{2}{*}{ \pm 1} & \multirow[t]{2}{*}{ \pm 300} & $215-0.02 \mathrm{hPa}$ \\
\hline & 1:45 p.m. & & $\mathrm{B}$ & $70^{\circ} \mathrm{S}-68^{\circ} \mathrm{N}$ & 16546 & & & $2-3 \mathrm{~km}$ \\
\hline \multirow[t]{2}{*}{ ACE-FTS } & Sunset/ & \multirow[t]{2}{*}{3.0} & A & $38^{\circ} \mathrm{S}-67.9^{\circ} \mathrm{N}$ & 308 & \multirow[t]{2}{*}{ \pm 12} & \multirow[t]{2}{*}{ \pm 300} & $5-110 \mathrm{~km}$ \\
\hline & sunrise & & $\mathrm{B}$ & $68^{\circ} \mathrm{S}-66^{\circ} \mathrm{N}$ & 122 & & & $3 \mathrm{~km}$ grid \\
\hline \multirow[t]{4}{*}{ ENVISAT/MIPAS } & 10:00 a.m./ & \multirow[t]{2}{*}{ V4O_O3_202 } & A & $42^{\circ} \mathrm{S}-66^{\circ} \mathrm{N}$ & 2485 & \multirow[t]{2}{*}{ \pm 1} & \multirow[t]{2}{*}{ \pm 300} & $4-44 \mathrm{~km}, 1 \mathrm{~km}$ grid \\
\hline & \multirow[t]{3}{*}{ 10:00 p.m. } & & B & $61^{\circ} \mathrm{S}-66^{\circ} \mathrm{N}$ & 2980 & & & $46-70 \mathrm{~km}, 2 \mathrm{~km}$ grid \\
\hline & & \multirow[t]{2}{*}{ V5O_O3_220 } & A & $42^{\circ} \mathrm{S}-66^{\circ} \mathrm{N}$ & 5544 & \multirow[t]{2}{*}{ \pm 1} & \multirow[t]{2}{*}{ \pm 300} & 4-44 km, $1 \mathrm{~km}$ grid \\
\hline & & & B & $61^{\circ} \mathrm{S}-66^{\circ} \mathrm{N}$ & 3389 & & & $46-70 \mathrm{~km}, 2 \mathrm{~km}$ grid \\
\hline \multirow[t]{2}{*}{ Odin/OSIRIS } & 6:00 a.m. & SaskMART & A & $71^{\circ} \mathrm{S}-67^{\circ} \mathrm{N}$ & 1623 & \multirow[t]{2}{*}{ \pm 1} & \multirow[t]{2}{*}{ \pm 300} & $5-64.5 \mathrm{~km}$ \\
\hline & 6:00 p.m. & 5.01 & $\mathrm{~B}$ & $71^{\circ} \mathrm{S}-67^{\circ} \mathrm{N}$ & 1355 & & & $1 \mathrm{~km}$ grid \\
\hline \multirow[t]{2}{*}{ Odin/SMR } & 6:00 a.m. & 2.1 & A & $67^{\circ} \mathrm{S}-67^{\circ} \mathrm{N}$ & 999 & \multirow[t]{2}{*}{ \pm 1} & \multirow[t]{2}{*}{ \pm 300} & $\sim 7-47 \mathrm{~km}, \sim 1.5 \mathrm{~km}$ grid \\
\hline & 6:00 p.m. & & B & $72^{\circ} \mathrm{S}-67^{\circ} \mathrm{N}$ & 843 & & & $\sim 50-70 \mathrm{~km}, \sim 5 \mathrm{~km}$ grid \\
\hline \multirow[t]{2}{*}{ SMILES (JAXA) } & \multirow[t]{2}{*}{ Variable } & \multirow[t]{2}{*}{$2.0(2.1)$} & A & $70^{\circ} \mathrm{S}-65^{\circ} \mathrm{N}$ & 72673 & & \multirow[t]{2}{*}{ All data } & $\sim 100 \mathrm{hPa}-0.0001 \mathrm{hPa}$ \\
\hline & & & $\mathrm{B}$ & $70^{\circ} \mathrm{S}-65^{\circ} \mathrm{N}$ & 79364 & & & $\sim 3 \mathrm{~km}$ grid \\
\hline \multirow[t]{2}{*}{ TELIS } & Local time & 2.1 & A & $65^{\circ} \mathrm{N}-67^{\circ} \mathrm{N}$ & 0 & & & \\
\hline & 12:45 p.m. & (L1b) & $\mathrm{B}$ & $65^{\circ} \mathrm{N}-67^{\circ} \mathrm{N}$ & 2 & \pm 1 & \pm 200 & $\sim 14-34 \mathrm{~km}, \sim 1.5 \mathrm{~km}$ grid \\
\hline Ozonesonde & - & - & A & $38^{\circ} \mathrm{S}-52^{\circ} \mathrm{N}$ & 163 & \pm 12 & \pm 300 & $0-30 \mathrm{~km}$ \\
\hline & & & $\mathrm{B}$ & $55^{\circ} \mathrm{S}-52^{\circ} \mathrm{N}$ & 134 & & & $\sim 50-100 \mathrm{~m}$ grid \\
\hline
\end{tabular}

limb scan and related calibration in $25 \mathrm{~s}$, and obtains $\sim 3500$ vertical profiles a day (Waters et al., 2006). The MLS data processing algorithms are based on the optimal estimation method, as explained by Livesey et al. (2006). MLS uses spectral bands centered near 118, 190, 240, and $640 \mathrm{GHz}$, as well as $2.3 \mathrm{THz}$, and obtains standard Level- $2 \mathrm{O}_{3}$ profiles from the $240 \mathrm{GHz}$ spectral region (Livesey et al., 2006).

The altitude range of a retrieved $\mathrm{MLS}_{3}$ profile for version 3.3 (hereafter v3.3) is represented on a pressure grid encompassing 37 levels, equally spaced on a log scale from 1000 to $1 \mathrm{hPa}$ (e.g., 1000, 825, 681, 562, 464, 383, 316, 261, $215,178,147,121$, and $100 \mathrm{hPa}$ for the first 13 levels), and including 18 levels (on a grid coarser by a factor of two) above $1 \mathrm{hPa}$ (Livesey et al., 2011).

We used the MLS v3.3 $\mathrm{O}_{3}$ product for the comparisons. Several MLS v2.2 validation studies have been published, e.g., Froidevaux et al. (2008), Dupuy et al. (2009), Chauhan et al. (2009), Jiang et al. (2007), and Livesey et al. (2008). According to Froidevaux et al. (2008), MLS v2.2 data exhibit differences of about 5-8\% over the stratosphere and lower mesosphere compared to other satellite datasets, ozonesondes, lidars, and ground-based microwave instruments. According to Dupuy et al. (2009), a comparison between MLS v2.2 and the ACE-FTS version $2.2 \mathrm{O}_{3}$ updated product shows 0 to $10 \%$ difference between 12 and $43 \mathrm{~km}(\sim 2 \mathrm{hPa})$ and 10 to $25 \%$ difference between 43 and $60 \mathrm{~km}$. Validation of MLS v3.3 data is currently in progress but shows very small ( 1 to $2 \%$ ) differences versus the MLS v2.2 data for most of the stratosphere (Livesey et al., 2011). However, vertical profile $\mathrm{O}_{3}$ oscillations have become pronounced mainly at low latitudes in the upper troposphere and lower stratosphere; this issue is currently being studied further by the MLS team, with improvements expected for the next data version. For the purposes of this work and the comparisons versus SMILES stratospheric $\mathrm{O}_{3}$ data, the use of either MLS v2.2 or v3.3 data would result in very similar conclusions; the main difference has to do with the finer (by a factor of two) vertical retrieval grid for the v3.3 data.

We performed the comparisons using MLS and SMILES profiles within $\pm 300 \mathrm{~km}$ and $\pm 1 \mathrm{~h}$, as mentioned in Sect. 4.1. We also used the MLS data screening recommendations from the MLS team (see Livesey et al., 2011). We used the data that satisfy the conditions for each profile, such that "Status" field is even, "Quality" $>0.6$, and "Convergence" $<1.18$. After data screening, we obtained 20583 and 16546 coincidences versus MLS profiles for the SMILES Band-A and Band-B retrievals, respectively.

The results are shown in Fig. 13. The relative differences between SMILES and MLS are -11 to $+3 \%$ between 40 and $2 \mathrm{hPa}(\sim 22-45 \mathrm{~km})$. The Band-B profile is very close 
Table 5. Summary of the ozonesonde stations used in the presented comparison.

\begin{tabular}{|c|c|c|c|c|c|c|c|}
\hline \multirow[t]{2}{*}{ Station } & \multirow[t]{2}{*}{ Location } & \multirow[t]{2}{*}{ Country } & \multirow[t]{2}{*}{ Agency } & \multirow[t]{2}{*}{ Type } & \multirow[t]{2}{*}{ Source } & \multicolumn{2}{|c|}{ No. of coincidences } \\
\hline & & & & & & Band-A & Band-B \\
\hline Legionowo & $52.4^{\circ} \mathrm{N}, 20.97^{\circ} \mathrm{E}$ & POL & PIMWM & $\mathrm{ECC}$ & WOUDC & 6 & 0 \\
\hline De Bilt & $52.1^{\circ} \mathrm{N}, 5.18^{\circ} \mathrm{E}$ & NLD & KNMI & ECC & WOUDC & 3 & 2 \\
\hline Valentia Obs. & $51.93^{\circ} \mathrm{N}, 10.25^{\circ} \mathrm{W}$ & IRL & $\mathrm{ME}$ & $\mathrm{ECC}$ & WOUDC & 22 & 18 \\
\hline Hohenpeissenberg & $47.8^{\circ} \mathrm{N}, 11.02^{\circ} \mathrm{E}$ & DEU & DWD & $\mathrm{BM}$ & WOUDC & 36 & 25 \\
\hline Sapporo & $43.06^{\circ} \mathrm{N}, 141.3^{\circ} \mathrm{E}$ & JPN & JMA & $\mathrm{CI}$ and $\mathrm{ECC}^{*}$ & WOUDC & 2 & 7 \\
\hline Madrid/Barajas & $40.47^{\circ} \mathrm{N}, 3.65^{\circ} \mathrm{W}$ & ESP & INME & $\mathrm{ECC}$ & WOUDC & 20 & 14 \\
\hline Ankara & $39.95^{\circ} \mathrm{N}, 32.88^{\circ} \mathrm{E}$ & TUR & TSMS & $\mathrm{ECC}$ & WOUDC & 5 & 3 \\
\hline Wallops Island & $37.93^{\circ} \mathrm{N}, 75.48^{\circ} \mathrm{W}$ & USA & NASA-WFF & $\mathrm{ECC}$ & WOUDC & 12 & 14 \\
\hline Tateno/Tsukuba & $36.06^{\circ} \mathrm{N}, 140.1^{\circ} \mathrm{E}$ & JPN & JMA & $\mathrm{CI}$ and $\mathrm{ECC}^{*}$ & WOUDC & 10 & 11 \\
\hline Isfahan & $32.51^{\circ} \mathrm{N}, 51.43^{\circ} \mathrm{E}$ & IRN & MDI & $\mathrm{ECC}$ & WOUDC & 4 & 6 \\
\hline Naha & $26.21^{\circ} \mathrm{N}, 127.7^{\circ} \mathrm{E}$ & JPN & JMA & $\mathrm{ECC}$ & WOUDC & 5 & 4 \\
\hline Hong Kong Obs. & $22.31^{\circ} \mathrm{N}, 114.2^{\circ} \mathrm{E}$ & HKG & $\mathrm{HKO}$ & ECC & WOUDC & 3 & 2 \\
\hline Alajuela & $9.98^{\circ} \mathrm{N}, 84.21^{\circ} \mathrm{W}$ & CRI & SHADOZ & $\mathrm{ECC}$ & SHADOZ & 0 & 3 \\
\hline Paramaribo & $5.81^{\circ} \mathrm{N}, 55.21^{\circ} \mathrm{W}$ & SUR & SHADOZ & ECC & SHADOZ & 3 & 1 \\
\hline Kuala Lumpur & $2.73^{\circ} \mathrm{N}, 101.7^{\circ} \mathrm{E}$ & MYS & SHADOZ & $\mathrm{ECC}$ & SHADOZ & 0 & 1 \\
\hline Nairobi & $1.27^{\circ} \mathrm{S}, 36.8^{\circ} \mathrm{E}$ & KEN & SHADOZ & ECC & SHADOZ & 1 & 0 \\
\hline Natal & $5.49^{\circ} \mathrm{S}, 35.33^{\circ} \mathrm{W}$ & BRA & SHADOZ & ECC & SHADOZ & 6 & 2 \\
\hline Wakutosek (Java) & $7.50^{\circ} \mathrm{S}, 112.6^{\circ} \mathrm{E}$ & IDN & SHADOZ & ECC & SHADOZ & 0 & 1 \\
\hline Ascension Island & $7.98^{\circ} \mathrm{S}, 14.42^{\circ} \mathrm{W}$ & GBR & SHADOZ & $\mathrm{ECC}$ & SHADOZ & 8 & 8 \\
\hline La Réunion & $21.06^{\circ} \mathrm{S}, 55.48^{\circ} \mathrm{E}$ & REU & SHADOZ & $\mathrm{ECC}$ & SHADOZ & 5 & 6 \\
\hline Broadmeadows & $37.69^{\circ} \mathrm{S}, 114.9^{\circ} \mathrm{E}$ & AUS & $\mathrm{ABM}$ & $\mathrm{ECC}$ & WOUDC & 8 & 4 \\
\hline Macquarie Island & $54.5^{\circ} \mathrm{S}, 159.0^{\circ} \mathrm{E}$ & AUS & $\mathrm{ABM}$ & ECC & WOUDC & 0 & 1 \\
\hline
\end{tabular}

* CI-type ozonesondes were used until 24 November 2009 and ECC-type ozonesondes were used from 2 December 2009.

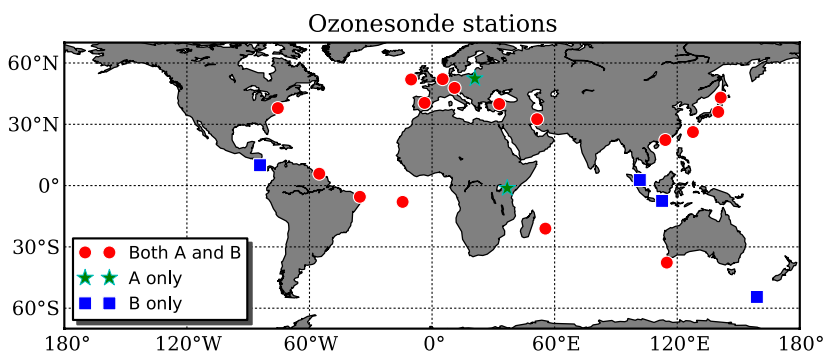

Fig. 11. Ozonesonde stations where coincidences were found in this study. Red dots are observation points where coincidences were found between ozonesondes and both Band-A and Band-B. Green stars are those where comparisons were between ozonesondes and Band-A. Blue squares are those for the comparison between ozonesondes and Band-B.

to the MLS one (within $1 \%$ difference) around $8-10 \mathrm{hPa}$ (where the stratospheric peak in $\mathrm{O}_{3}$ VMR exists), while the SMILES Band-A product is larger than that of MLS by $+3 \%$ $(\sim 0.2 \mathrm{ppmv})$. Above $45 \mathrm{~km}$, the relative differences are negative and worse than $-10 \%$. The vertical trend of the difference is roughly similar to that of the SMILES internal comparison between SMILES(NICT) and SMILES(JAXA) (Fig. 8); but in detail one can observe that the amplitude of the difference in the SMILES(NICT)-MLS comparison decreases from -0.6 to $-0.2 \mathrm{ppmv}$ (from 1 to $0.1 \mathrm{hPa}$ ) while the SMILES(NICT)-SMILES(JAXA) comparison showed a constant -0.1 ppmv difference in that pressure range. In Sect. 3.2, we discussed that the difference of SMILES and SMILES(JAXA) most likely comes from the impact of the different tangent height correction procedures. The result shown in Fig. 13 (which has a different vertical trend compared to the SMILES(NICT) and SMILES(JAXA) comparison) means that the difference between SMILES(NICT) and MLS data at higher altitudes is not solely due to the tangent height correction issue. One potential error source that could explain this difference is the uncertainty in the modeling of the SMILES AOS response function. Indeed, if we compare MLS with the SMILES(NICT) Band-A data for the different AOSs, AOS1 and AOS2, in Fig. 14, we find that the SMILES(NICT)-MLS difference is not exactly the same at $1 \mathrm{hPa}$ for AOS1 and AOS2 (-0.5 versus $-0.65 \mathrm{ppmv})$.

The more significant difference shown at $\sim 10 \mathrm{hPa}$ in Fig. 14 is due to the effect of uncertainty in the nonlinearity gain calibration. The result is consistent with what we learned from the SMILES(NICT)-SMILES(JAXA) comparison shown in Fig. 8, that is the SMILES $\mathrm{O}_{3}$ profile obtained with Band-A AOS2 tends to have larger VMR at $10-8 \mathrm{hPa}$ compared to that obtained with Band-A AOS1. Note that the differences between AOS1 and AOS2 are more moderate than those inferred in Fig. 8. This is because this result is calculated with the coincident pairs from all latitudes 


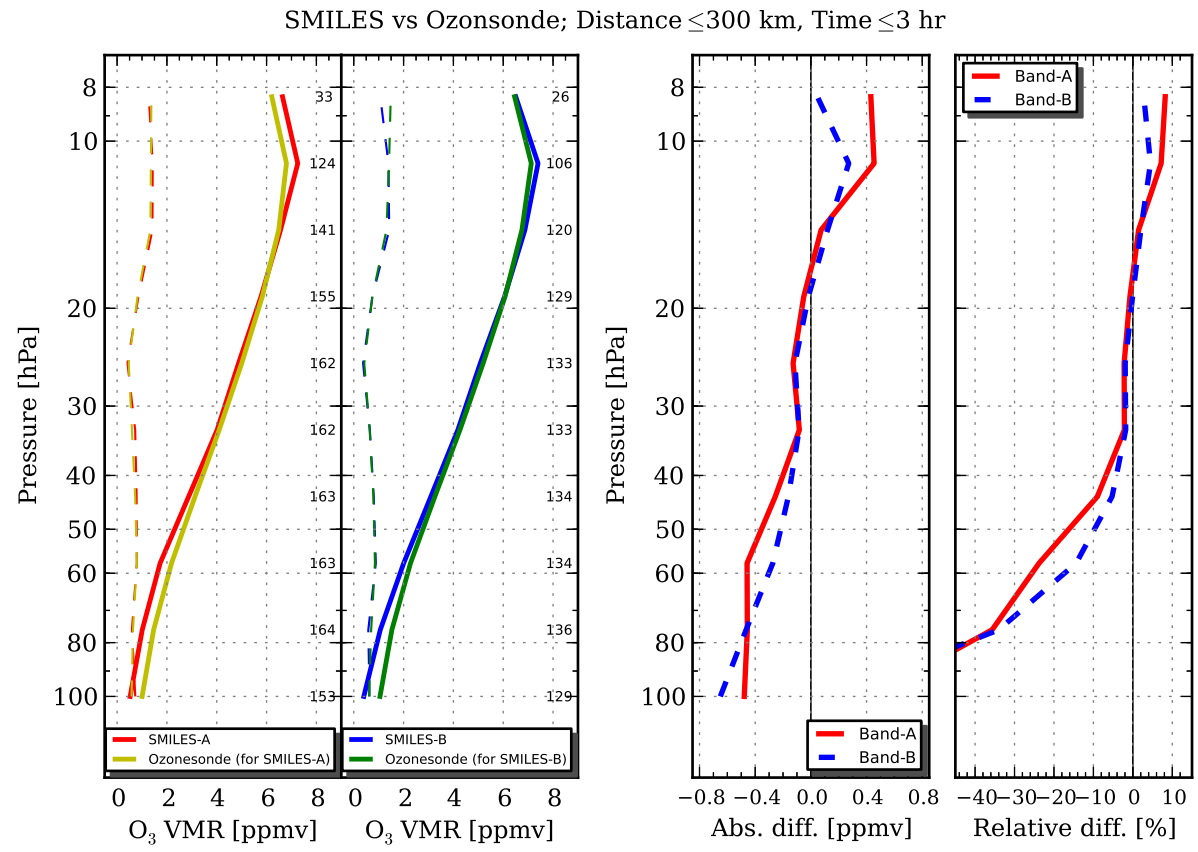

Fig. 12. Left panel: mean $\mathrm{O}_{3}$ VMR values for SMILES and ozonesonde measurements (solid lines). The SMILES measurements for BandA (red line) and Band-B (blue line) are compared separately. Dashed lines represent the associated $1 \sigma$ standard deviations for each dataset. Numbers of coincident pairs are indicated at the right side of each panel. Middle panel: mean absolute difference for observed $\mathrm{O}_{3}$ between SMILES and ozonesonde calculated by Eq. (2). The comparisons for Band-A and for Band-B measurements are shown with the red solid and blue dashed profiles, respectively. Right panel: mean relative difference for observed $\mathrm{O}_{3}$ between SMILES and ozonesonde calculated by Eq. (3).
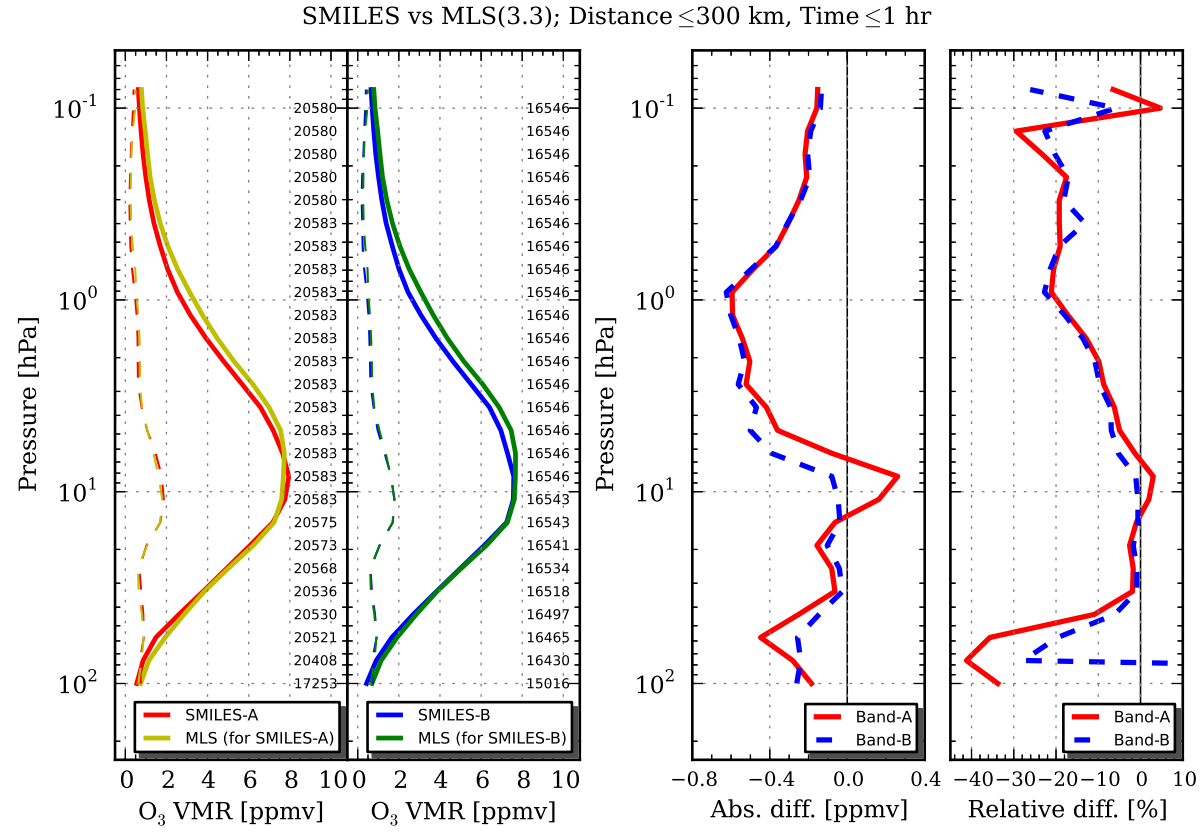

Fig. 13. Comparison between SMILES and MLS O 3 profiles. See Fig. 12 for the plot format. 

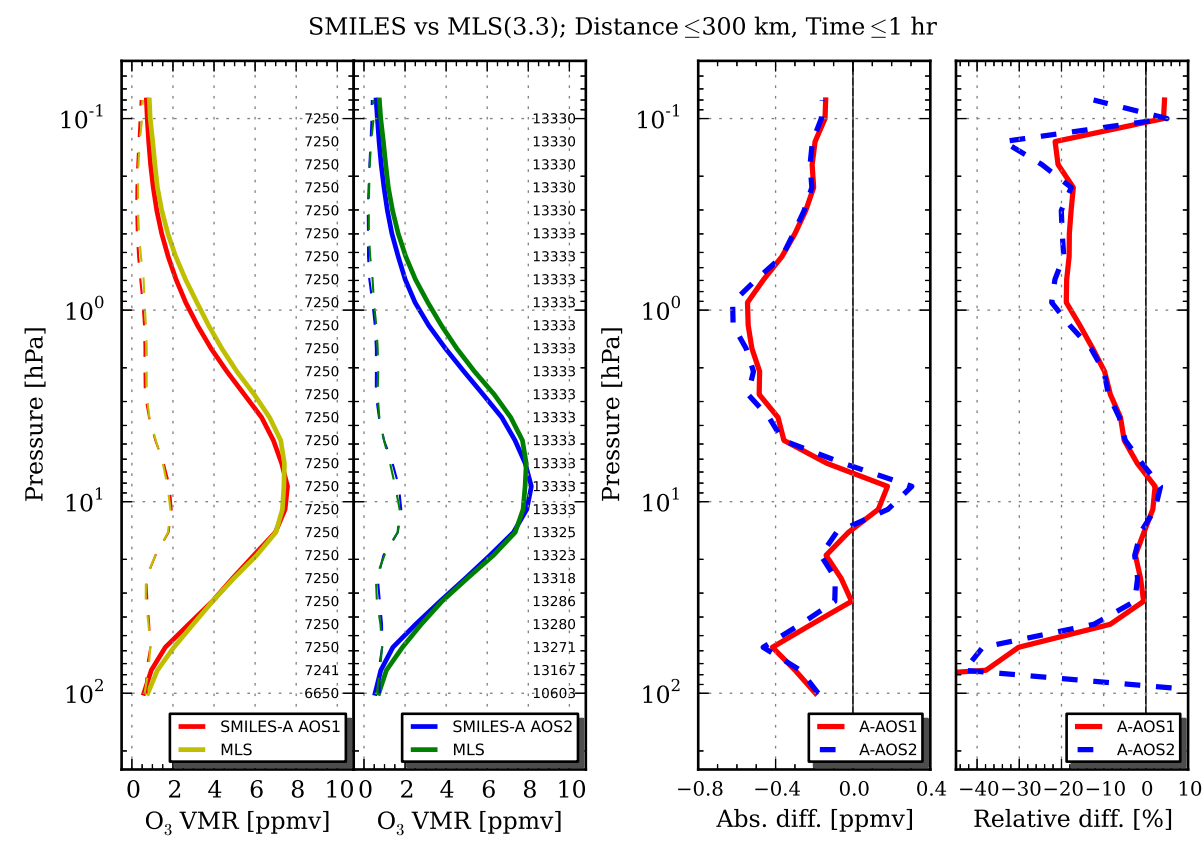

Fig. 14. Same as Fig. 13, except we selected the SMILES data only for Band-A and distinguished the two different AOSs used.

while Fig. 8 was created using using only equatorial data, where larger differences exist between the AOSs (as shown in Fig. 10).

Improvements in the AOS response function parameterization are targeted for the next version of SMILES L1b calibration. It will be interesting to see how this changes the comparisons versus MLS at high altitudes.

The seasonal and latitudinal variation of the relative difference at $8.3 \mathrm{hPa}$ is shown in Fig. 15. The coincident pairs were divided into 2-day and $10^{\circ}$-latitude pixels, and the median value of the relative differences were calculated for each pixel. Only the pixels where we had more than five coincident pairs are shown. Similar to the results shown in the SMILES internal comparison section, the relative differences are largest in the tropics. For Band-A (both AOS1 and AOS2 were combined), the SMILES(NICT) and MLS difference was +10 to $+15 \%$ (note that the result shown in Fig. 13 is a global and seasonal average). Results from Band-B show a similar latitudinal and seasonal dependence as those from Band-A. Some abnormal pixel differences are observed for $60^{\circ} \mathrm{S}$ in the middle of February, when SMILES observed high southern latitudes $\left(69^{\circ} \mathrm{S}\right)$.

\subsubsection{SCISAT/ACE-FTS}

The Canadian-led science mission, the Atmospheric Chemistry Experiment (ACE) on the SCISAT satellite, was launched on 12 August 2003. The ACE satellite moves along an orbit inclined at $74^{\circ}$ to the equator at $650 \mathrm{~km}$ altitude (Bernath et al., 2005). The ACE satellite has two instruments: the ACE Fourier Transform Spectrometer (ACE-

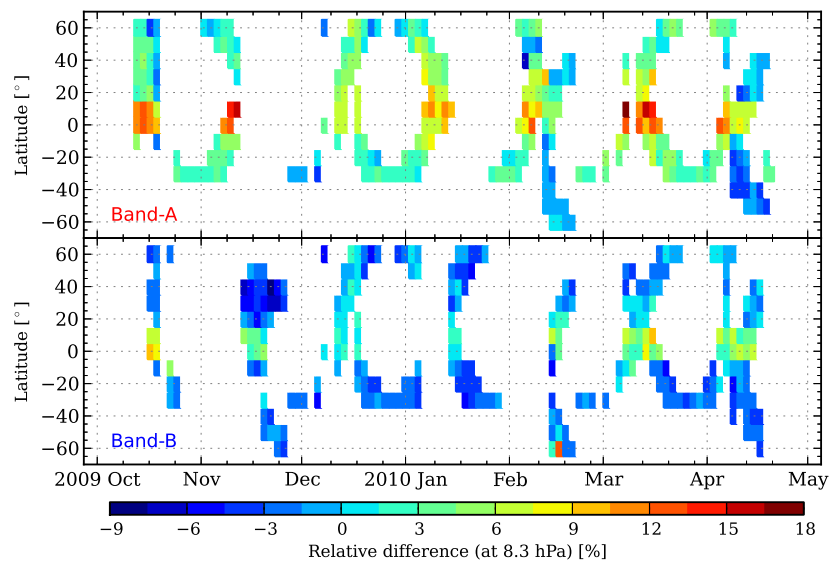

Fig. 15. Seasonal and latitudinal change of the relative differences between SMILES and MLS $\mathrm{O}_{3}$ VMRs. The value for the $8.3 \mathrm{hPa}$ level is shown. The inhomogeneous data coverage is because the SMILES orbit is non-sun-synchronizing.

FTS) (Bernath et al., 2005) and the Measurement of Aerosol Extinction in the Stratosphere and Troposphere Retrieved by Occultation (ACE-MAESTRO) (McElroy et al., 2007). These observe the vertical profiles of $\mathrm{O}_{3}$ and a myriad of other trace gas constituents, temperature, and atmospheric extinction by aerosols.

The ACE-FTS measures the absorption of solar infrared radiation $\left(750-4400 \mathrm{~cm}^{-1}\right)$ with a high resolution of $0.02 \mathrm{~cm}^{-1}$. It observes sunrise and sunset about 30 times $(15+15)$ per day and measures from cloud top to $\sim 150 \mathrm{~km}$ with a vertical resolution of about $3-4 \mathrm{~km}$. The latitude range 


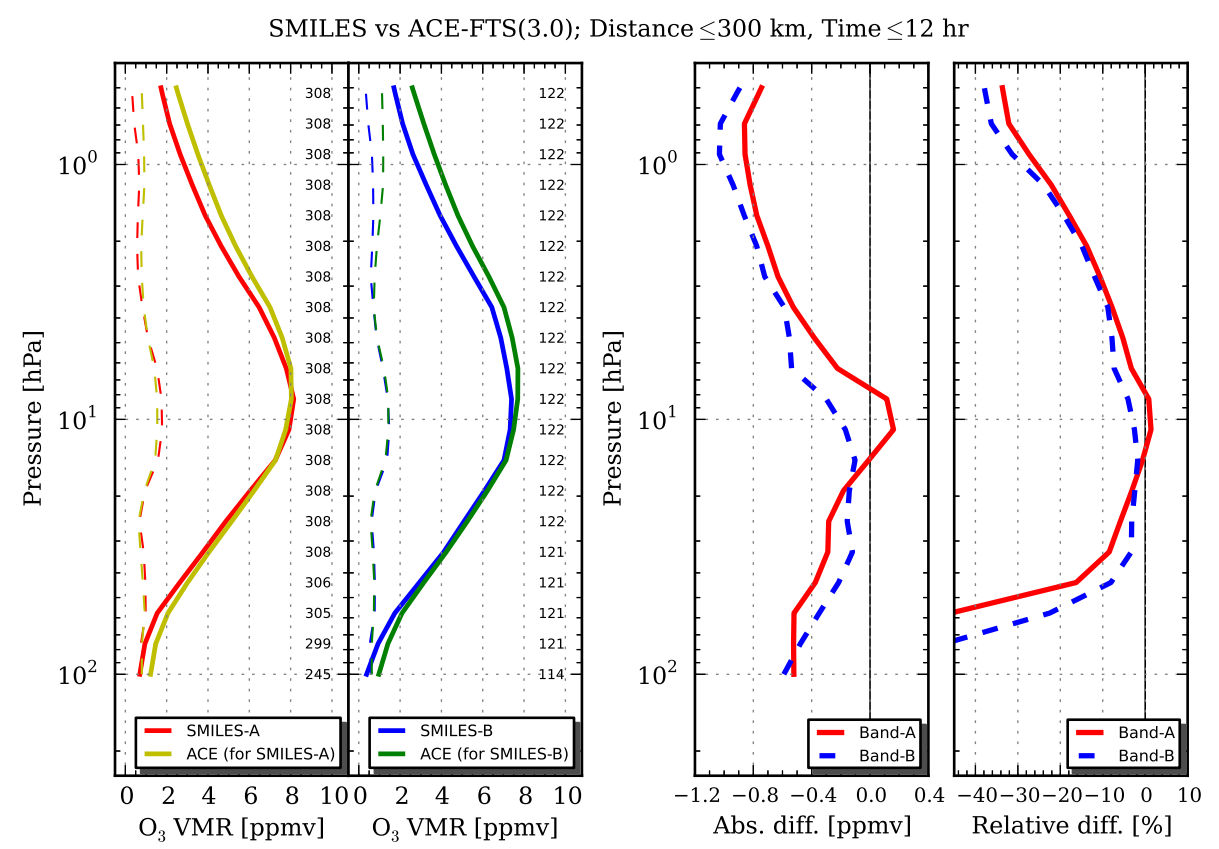

Fig. 16. Comparison between SMILES and ACE-FTS $\mathrm{O}_{3}$ profiles. See Fig. 12 for the plot format.

covered by ACE-FTS extends from $85^{\circ} \mathrm{S}$ to $85^{\circ} \mathrm{N}$, as given in Bernath et al. (2005).

The retrieval method is based on the LevenbergMarquardt nonlinear least-squares method. Detailed information is given in Boone et al. (2005). The $\mathrm{O}_{3}$ vertical profiles are obtained from observed $\mathrm{O}_{3}$ spectra in the frequency region of $829 \mathrm{~cm}^{-1}, 923 \mathrm{~cm}^{-1}, 1027-1168 \mathrm{~cm}^{-1}$, $2149 \mathrm{~cm}^{-1}$, and $2566-2673 \mathrm{~cm}^{-1}$. The retrieved data for $\mathrm{O}_{3}$ have a vertical profile range from $\sim 10 \mathrm{~km}$ to $>90 \mathrm{~km}$ with $1 \mathrm{~km}$ spacing after interpolation (Boone et al., 2005).

We compared the SMILES v2.1.5 data (Band-A and BandB) and the ACE-FTS version 3.0 data. The latest data version of ACE-FTS (version 3.0) is being validated including comparisons with the previous version (version $2.2 \mathrm{O}_{3}$ ) (Waymark et al., 2011). ACE-FTS $\mathrm{O}_{3}$ (version 3.0) profiles are improved compared to the v2.2 update profiles, with a 5$10 \%$ decrease in VMR above $40 \mathrm{~km}$.

Comparison results between ACE-FTS and SMILES (Band-A and Band-B) are shown in Fig. 16. Criteria are set as $300 \mathrm{~km}$ and $\pm 12 \mathrm{~h}$ to obtain a sufficient number of coincidences. 308 and 122 coincidences were obtained for SMILES Band-A and Band-B, respectively. The SMILES $\mathrm{O}_{3}$ profiles have smaller VMRs at all heights except at $10 \mathrm{hPa}$ for the Band-A data. There is a difference of -15 to $-3 \%$ for Band-B, and $+1 \%$ for Band-A at pressures of $40-1 \mathrm{hPa}$. The magnification of the difference is more significant than that of MLS. This is mainly due to a larger observation time difference $(12 \mathrm{~h})$ in the coincidence search.

\subsubsection{ENVISAT/MIPAS}

The Michelson Interferometer for Passive Atmospheric Sounding (MIPAS) is a mid-infrared emission spectrometer, which was a core payload of the European ENVIronmental SATellite (ENVISAT) launched on 1 March 2002 (Fischer et al., 2008). ENVISAT moved at an altitude of $800 \mathrm{~km}$ and had a sun-synchronous orbit with $98.55^{\circ}$ inclination. The descending equator crossing time was 10:00.

MIPAS observed five mid-infrared spectral bands within the frequency range 685 to $2410 \mathrm{~cm}^{-1}(14.6-4.15 \mu \mathrm{m})$ with a resolution of $0.0625 \mathrm{~cm}^{-1}$ (Cortesi et al., 2007). From 6 July 2002 to 26 March 2004, MIPAS scanned 17 tangent altitudes from 6 to $68 \mathrm{~km}$ with $3-8 \mathrm{~km}$ resolution. The spectral resolution was $0.025 \mathrm{~cm}^{-1}$. At the end of March 2004, excessive anomalies observed in the interferometer led to temporary discontinuation. However, it started again in a new operation mode from January 2005 . In this operational mode, MIPAS scanned at a reduced spectral resolution $\left(0.0625 \mathrm{~cm}^{-1}\right)$ and finer altitude grid. The latitudinal observation coverage was from $87^{\circ} \mathrm{S}$ to $89^{\circ} \mathrm{N}$. In the latter mode, MIPAS had about 95 scans per orbit and conducted about 14.3 orbits per day around the Earth. Thus, about 1360 vertical profiles were recorded in a day.

An L2 process has two kinds of retrieval data: operational data and scientific data (Fischer et al., 2008). The operational data are generated by ESA and contain the vertical profiles of temperature and six trace gases. However, several types of scientific data for trace gases exist that are not included in the ESA operational data. In this study, we used version V4O_O3_202 of the MIPAS scientific data product, which is 


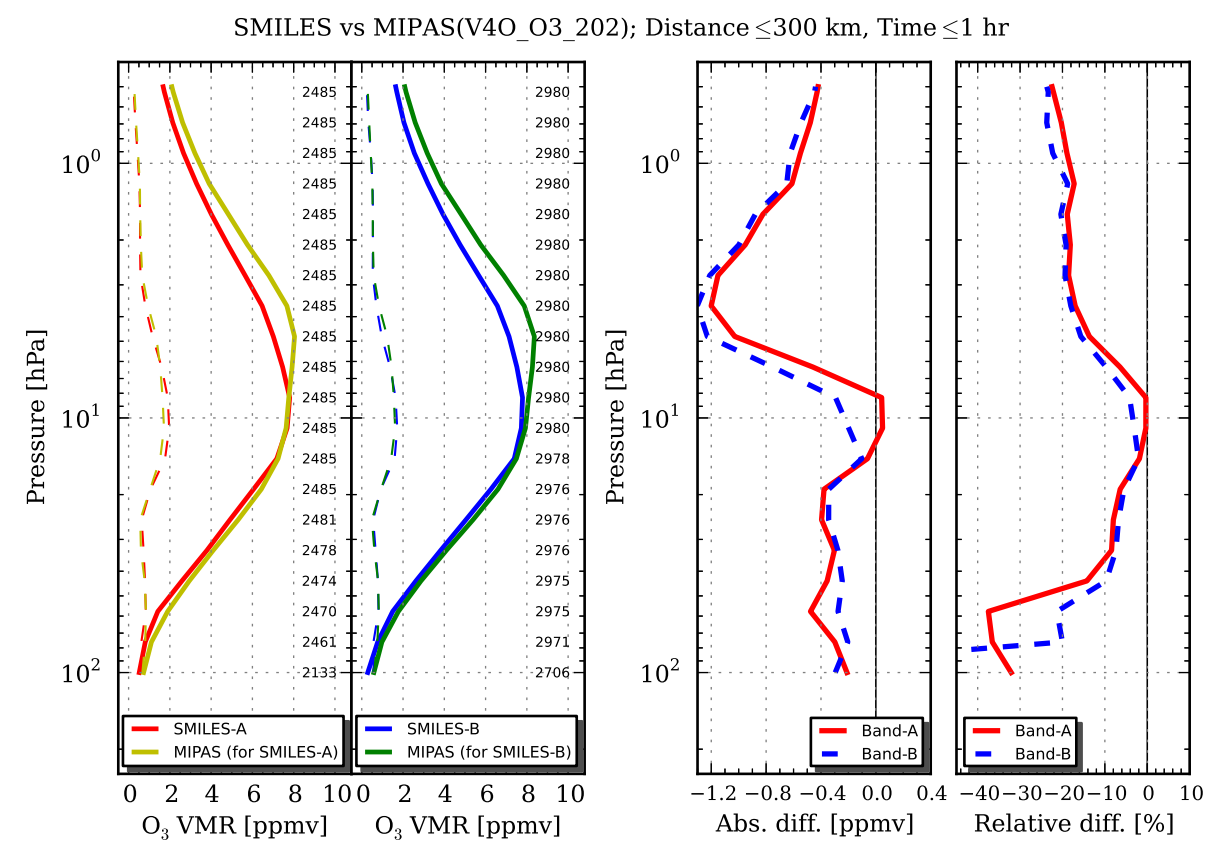

Fig. 17. Comparison between SMILES and MIPAS V4O_O3_202 O 3 profiles. See Fig. 12 for the plot format.

generated by Institut für Meteorologie und Klimaforschung (IMK) at Karlsruhe Institute of Technology (KIT) (von Clarmann et al., 2009). This data product was retrieved using a Tikhonov-type regularization with a smoothing constraint (Steck and von Clarmann, 2001).

MIPAS IMK-AAF (The Institute for Meteorology and Climate Research, the Atmospheric Aerosol Research) version V3O_O3_7 data were compared with lidars, FTIR, balloonborne instruments, and two satellite instruments (HALOE and POAM III) by Steck et al. (2007). According to that study, the mean relative differences for all instruments are between $\pm 10 \%$ above $18 \mathrm{~km}$ and 20 to $30 \%$ below $18 \mathrm{~km}$. In addition, the precision is $5-10 \%$ between $\sim 20$ and $55 \mathrm{~km}$, and the accuracy is $15-20 \%$ between 20 and $55 \mathrm{~km}$. The first version of the reduced spectral resolution L2 data product, version V4O_O3_202, was compared with measurement data obtained by lidars, ozonesonde data, and satellite instruments during the Measurements of Humidity in the Atmosphere and Validation Experiments (MOHAVE) 2009 campaign (Stiller et al., 2012). According to Stiller et al. (2012), the differences between the MIPAS $\mathrm{O}_{3}$ mean profile and mean profiles of most instruments were within $\pm 0.3 \mathrm{ppmv}$ below $30 \mathrm{~km}$. These MIPAS $\mathrm{O}_{3}$ profiles have a positive bias up to $+0.9 \mathrm{ppmv}$ at $37 \mathrm{~km}$. Between 50 and $60 \mathrm{~km}$, a -0.5 ppmv difference is found in the comparison between MIPAS profiles and ACE-FTS version $2.2 \mathrm{O}_{3}$ profiles. However, the ACE-FTS version $2.2 \mathrm{O}_{3}$ data have a positive bias from 45 to $60 \mathrm{~km}$, as mentioned in Sect. 4.3.2. The positive MIPAS $\mathrm{O}_{3}$ bias around $37 \mathrm{~km}$ has been largely reduced in the V5O_O3_220 version. The current status of the MIPAS data comparisons are reported by Laeng et al. (2012).
We performed the comparisons with $\pm 300 \mathrm{~km}$ in a great circle and $\pm 1 \mathrm{~h}$, as mentioned in Sect. 4.1. With these criteria, 2485 and 2980 coincidences with MIPAS version V4O_O3_202 profiles were found for Band-A and Band-B, respectively. The results are shown in Fig. 17. Comparison with MIPAS confirms the result of the SMILES validation with MLS and ACE-FTS that SMILES ozone mixing ratios are low, except for the Band-A at the $10 \mathrm{hPa}$ level. It is shown that the absolute difference has a local minimum of -1.2 ppmv around $3-4 \mathrm{hPa}$ (about $40 \mathrm{~km}$ ). This can be explained by the fact that the version of MIPAS data considered has a positive bias at these altitudes. If this localized bias of +0.9 ppmv for MIPAS (Stiller et al., 2012) is taken into account, the difference between SMILES and MIPAS (V4O) becomes $-0.3 \mathrm{ppmv}$ at the 3-4 hPa level. Comparison with the other instruments used in this study, however, suggest that the bias of MIPAS at this altitude is more likely about +0.5 ppmv only and that the value of +0.9 ppmv as determined from the MOHAVE intercomparisons might not be representative for the wider range of atmospheric conditions encountered in this study. The comparison with the MIPAS V5O_O3_220 dataset is shown in Fig. 18. We found better agreement at altitudes below $3 \mathrm{hPa}$, while differences remain large at $2-3 \mathrm{hPa}$.

\subsubsection{Odin/OSIRIS}

Odin (Murtagh et al., 2002) is a scientific mission led by Sweden partnered with France, Canada, and Finland, and was launched on 20 February 2001. Odin is in a circular, $620 \mathrm{~km}$ altitude, sun-synchronous and near-terminator orbit 


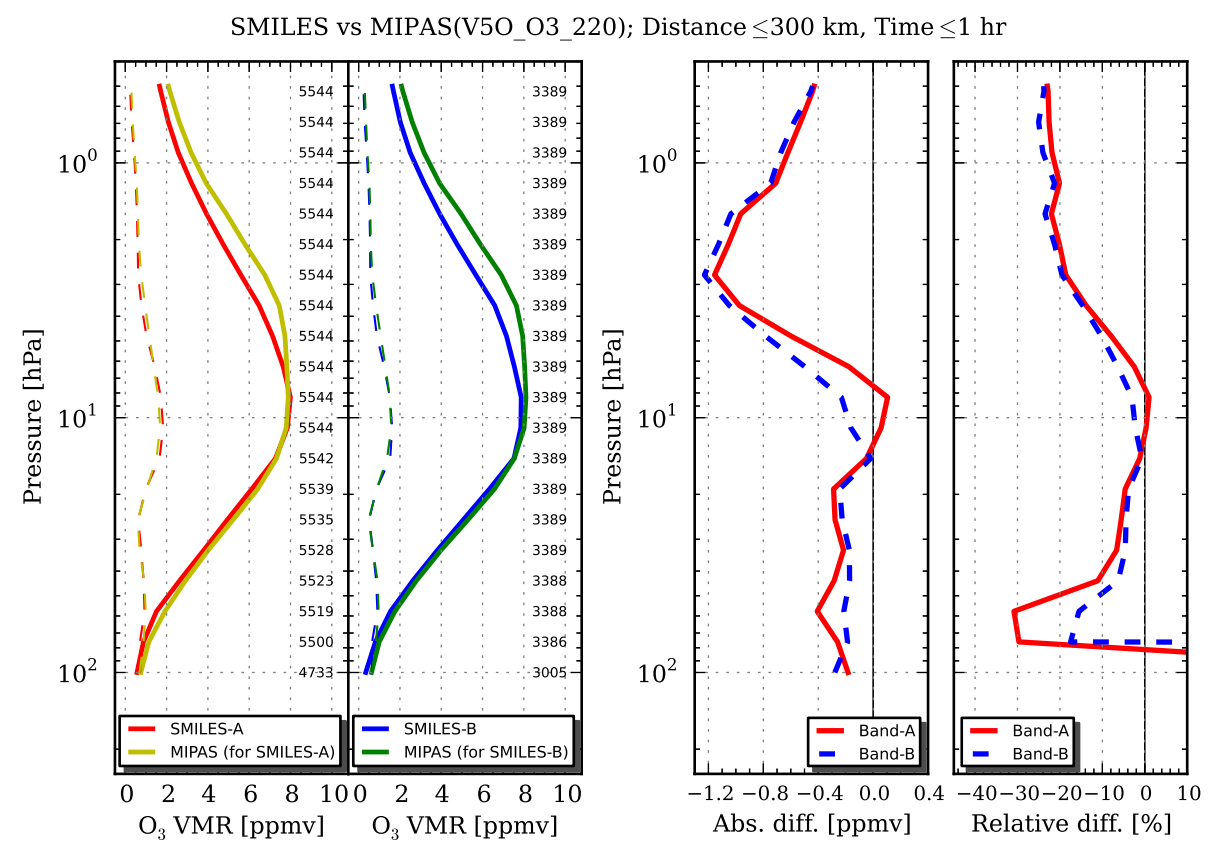

Fig. 18. Same with Fig. 17 but using MIPAS V5O_O3_220 dataset.

with the ascending node near 18:00 LT (local time). Its orbit is near-polar with an inclination of $97.8^{\circ}$, so the maximum coverage of the orbit plane ranges from $82.2^{\circ} \mathrm{N}$ to $82.2^{\circ} \mathrm{S}$. Two types of instruments are mounted on Odin: the Sub-Millimetre Radiometer (SMR) and the Optical Spectrograph and InfraRed Imager System (OSIRIS) (Llewellyn et al., 2004). They observe the molecules linked to $\mathrm{O}_{3}$ depletion, such as $\mathrm{O}_{3}, \mathrm{HNO}_{3}, \mathrm{NO}, \mathrm{NO}_{2}, \mathrm{ClO}, \mathrm{BrO}, \mathrm{H}_{2} \mathrm{O}$, $\mathrm{HO}_{2}, \mathrm{H}_{2} \mathrm{O}_{2}, \mathrm{OClO}, \mathrm{CO}, \mathrm{HDO}$, and $\mathrm{N}_{2} \mathrm{O}$. OSIRIS measures limb-scattered sunlight within the wavelength range of 280$800 \mathrm{~nm}$ with a spectral resolution of approximately $1 \mathrm{~nm}$. For the retrieval of ozone, OSIRIS performs a vertical limb scan with a $1 \mathrm{~km}$ vertical field-of-view over the altitude range of 7-65 km. Nominally OSIRIS generates approximately 30 $\mathrm{O}_{3}$ profiles per orbit over the sunlit hemisphere. However, two times a year 60 profiles are generated when Odin flies near the orbital terminator. These times occur in late February to early March and through September and October. We used the latest version (version 5.07) of the $\mathrm{O}_{3}$ data products processed at the University of Saskatchewan (Saskatoon, Canada). The $\mathrm{O}_{3}$ abundance in this product was retrieved with the SaskMART Multiplicative Algebraic Reconstruction Technique (Degenstein et al., 2009) and the SASKTRAN radiative transfer model (Bourassa et al., 2007). This technique uses the Chappuis and Hartley-Huggins absorption bands measured within the limb-scattered spectra. This retrieval algorithm obtains the $\mathrm{O}_{3}$ profiles from the cloud top to $60 \mathrm{~km}$. In Degenstein et al. (2009), they compared the retrieved OSIRIS $\mathrm{O}_{3}$ with coincident retrievals made using measurements from the Stratospheric Aerosol and Gas Experiment (SAGE) II. Their results show that the relative dif- ference between the two datasets is less than $2 \%$ between 18 and $53 \mathrm{~km}$. The standard deviation of the relative difference is approximately $5 \%$ between 20 and $50 \mathrm{~km}$, while the results show more than a $10 \%$ low bias above $53 \mathrm{~km}$ and $10 \%$ high bias below $18 \mathrm{~km}$.

We performed the comparisons with $\pm 300 \mathrm{~km}$ in a great circle and $\pm 1 \mathrm{~h}$, as mentioned in Sect. 4.1. With those criteria, 1623 and 1355 coincidences were found for Band-A and Band-B, respectively. The results are shown in Fig. 19. The SMILES Band-B data shows satisfactory agreement within a $0-+2 \%$ relative difference at the $20-10 \mathrm{hPa}$ range. Below and above this range, the difference amplitude increases to $-15 \%$ at 60 and $2 \mathrm{hPa}$ levels.

\subsubsection{Odin/SMR}

The Sub-Millimetre Radiometer (SMR) is the second instrument on board the Odin satellite. The Odin satellite is described in Sect. 4.3.4. Odin/SMR observes thermal emission at the atmospheric limb using four channels between 486 and $581 \mathrm{GHz}$. The measured receiver noise temperatures are $\sim 3000 \mathrm{~K}$ for the submillimeter channels (Murtagh et al., 2002). Stratospheric $\mathrm{O}_{3}$ is measured in two bands centered at 501.8 and $544.6 \mathrm{GHz}$. Measurements in this mode were performed on every third day starting at the beginning of this mission and since 2007 on every other day. The atmosphere is scanned from about 8 to $70 \mathrm{~km}$ with a vertical scan speed of $0.75 \mathrm{~km} \mathrm{~s}^{-1}$ and up to 1000 vertical profiles are obtained per measurement day (Merino et al., 2002; Urban et al., 2005).

In this study, we used the latest official version of the $\mathrm{O}_{3}$ data product, Version 2.1 (here after Chalmers-v2.1), which 


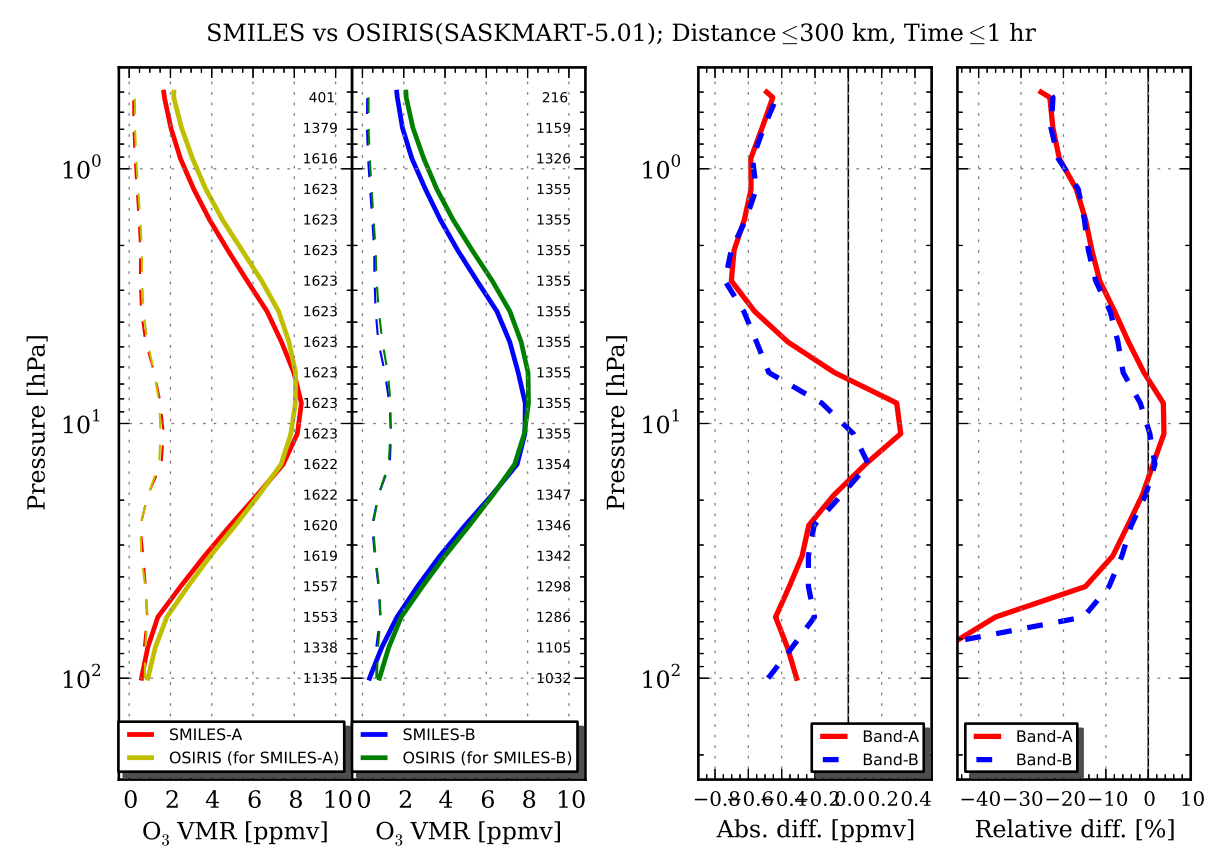

Fig. 19. Comparison between SMILES Band-A and OSIRIS. Same key as in Fig. 16.

is produced at the Chalmers University of Technology, Göteborg, Sweden. The Chalmers-v2.1 $\mathrm{O}_{3}$ data were retrieved from a weak $\mathrm{O}_{3}$ line near $501.5 \mathrm{GHz}$. The retrieval is based on the OEM method (Rodgers, 2000). The $501.8 \mathrm{GHz}$ v-2.1 $\mathrm{L} 2$ product provides stratospheric $\mathrm{O}_{3}$ data in the $\sim 12-60 \mathrm{~km}$ range with $2.5-3.5 \mathrm{~km}$ vertical resolution and single-profile precision of about $20 \%$. The systematic error is estimated to be smaller than $0.75 \mathrm{ppmv}$ (Urban et al., 2005, 2006).

Jones et al. (2007) compared three versions of the SMR $\mathrm{O}_{3}$ data (Chalmers-v2.1, v1.2, and v2.0) to MIPAS measurements. The results of the comparison between MIPAS and Chalmers-v2.1 are similar to the older versions in the altitude range from 25 to $45 \mathrm{~km}$ (less than $10 \%$ relative difference and 0.4 ppmv absolute difference), while the comparison shows the smallest differences between 19 and $25 \mathrm{~km}$ ( 0.25 ppmv and $\sim 5-7 \%)$, compared to the older versions. The relative difference is about $25 \%$ near the $\mathrm{O}_{3}$ peak. Jones et al. (2007) also made comparisons with ozonesondes. These results are similar between 25 and $35 \mathrm{~km}( \pm 0.5 \mathrm{ppmv}$ and approximately $\pm 10 \%$ ), but Chalmers-v2.1 shows small differences (of $\sim 0.3 \mathrm{ppmv}$ or less than $20 \%$ above $17 \mathrm{~km}$ ) to MIPAS below $25 \mathrm{~km}$.

We made the comparisons within a $\pm 300 \mathrm{~km}$ great circle and with a time difference of $\pm 1 \mathrm{~h}$ as mentioned in Sect. 4.1. According to Urban et al. (2005), it is recommended to use only data with measurement response larger than $\sim 0.9$ and zero for the profile quality flag. With these conditions, 999 and 843 coincidences were found for SMILES Band-A and Band-B, respectively. The results are shown in Fig. 20, which depict a different feature from all the previous comparisons described in this section.
SMR Chalmers-v2.1 and SMILES Band-B show an excellent agreement in the mean relative difference to within $0-7 \%$. Relative differences increase with altitude and the largest values are found at the upper end of the vertical range $(50-1 \mathrm{hPa})$. Differences with Band-A of up to $10 \%$ are found close to the ozone peak altitude.

With this SMILES-SMR comparison, the mismatch between the mean of absolute and relative differences are clearly illustrated. For example, the mean difference at $2 \mathrm{hPa}$ is almost 0 ppmv in the absolute difference but is $+5 \%$ in the relative one. Reminding our definition for the mean calculation of absolute and relative differences (Eqs. 2, 3), such a feature can be explained if SMILES tends to have a relatively smaller $\mathrm{O}_{3}$ volume mixing ratio compared to SMR (i.e., negative absolute difference) when either or both instruments measured a large $\mathrm{O}_{3}$ abundance (then, the relative difference is still negative but the amplitude becomes smaller). Figure 21 shows the correlation between the measured $\mathrm{O}_{3}$ volume mixing ratios and the corresponding absolute difference of SMILES-SMR comparison. It clearly shows that the $\mathrm{SMR}$ measured $\mathrm{O}_{3}$ abundance is distributed over a much wider range compared to that of SMILES, which is due to the lower sensitivity of the Odin/SMR instrument. Actually, this is also shown in the standard deviation of the $\mathrm{SMR} \mathrm{O}_{3}$ profile in the left panels of Fig. 20.

\subsection{Balloon-borne instruments, TELIS}

TELIS (TErahertz and submillimeter LImb Sounder) is a stratospheric balloon-borne cryogenic heterodyne spectrometer. The instrument utilizes state-of-the-art 


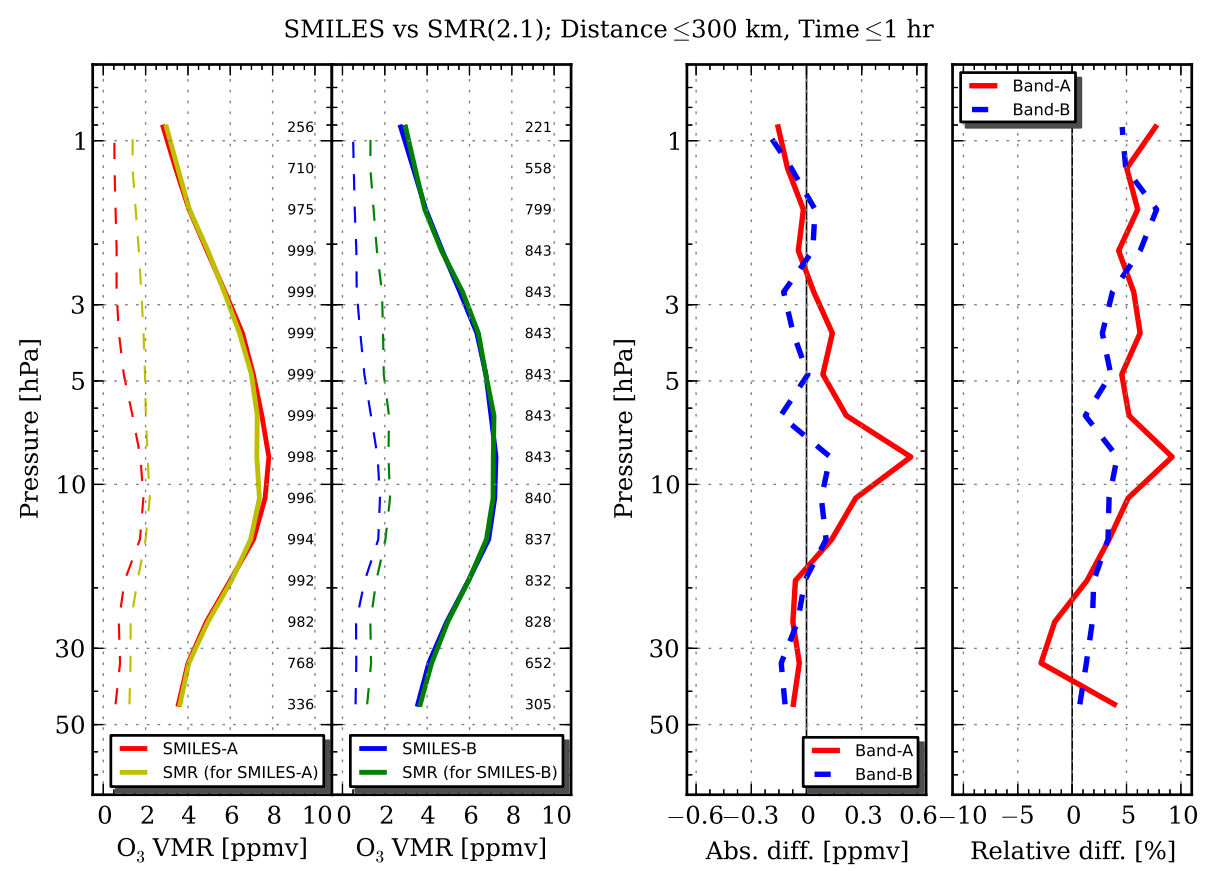

Fig. 20. Comparison between SMILES Band-A and SMR. Same key as in Fig. 16.

superconducting heterodyne technology and allows limb sounding of the upper troposphere and stratosphere with $1.5-2 \mathrm{~km}$ altitude resolution. TELIS has three frequency channels: a tunable $1.8 \mathrm{THz}$ channel (Suttiwong et al., 2009) using a superconducting hot-electron bolometer (HEB) mixer with high sensitivity, a $480-650 \mathrm{GHz}$ channel (de Lange et al., 2010) based on superconducting integrated receiver (SIR) technology, and a highly compact $500 \mathrm{GHz}$ channel. The instrument has participated in three scientific campaigns in Kiruna, Sweden, in Winter 2009, 2010, and 2011 as a payload of the MIPAS-B gondola.

The TELIS Level-1 data product consists of radiometric calibrated limb spectra, together with the geolocation information, the sideband ratio and the antenna beam profile. During flight, a short-term linear calibration approach is employed. An on-board blackbody unit is used as a hot signal reference and the signal from pointing into deep space is used as a cold signal reference. Nonlinearities present in the TELIS intermediate frequency(IF) signal chain are characterized via gas cell measurements on ground and are corrected for in the measured spectra in the radiometric calibration process. The sideband ratio as well as the antenna beam profiles of each channel have been characterized in laboratory measurements and so far have been found to be stable over time and during in-flight conditions.

The retrieval code PILS (Profile Inversion for Limb Sounding) is currently used for TELIS L2 data processing $(\mathrm{Xu}, \mathrm{J}$.$) . The forward model is based on the line-by-line$ program GARLIC (Generic Atmospheric Radiation Lineby-line Infrared Code) that is a modern Fortran reimple- mentation of MIRART (Modular InfraRed Atmospheric Radiative Transfer) (Schreier and Schimpf, 2001). MIRART has been thoroughly cross-validated against other radiative transfer codes (e.g., von Clarmann et al., 2002; Melsheimer et al., 2005). The inversion module is implemented within a constrained nonlinear least-squares optimization framework. Multi-parameter Tikhonov regularization is utilized to stabilize the iterative process. Jacobians with respect to the molecular concentration profiles are evaluated by means of automatic differentiation.

$\mathrm{O}_{3}$ was retrieved from a limb scan in the TELIS $1.8 \mathrm{THz}$ channel observed on 24 January 2010 . Temperature and pressure were taken from MIPAS-B retrievals (Wetzel et al., 2012) and ECMWF, respectively.

The retrieval is performed on an altitude grid discretized in $1.5 \mathrm{~km}$ between 16 and $32.5 \mathrm{~km}$, which is equivalent to the tangent spacing, and coarser steps above $32.5 \mathrm{~km}$. In Fig. 22, the TELIS retrieval result and the corresponding averaging kernel are shown. Two SMILES profiles are taken for comparison due to the close geolocation and time match. Large discrepancies occur above $34 \mathrm{~km}$ due to the limited information obtained by the TELIS instrument above the observing altitude. Apart from that, a rather good agreement between SMILES and TELIS is found between 16 and $31 \mathrm{~km}$.

\subsection{Summary of the $\mathrm{O}_{3} \mathrm{VMR}$ profiles comparison}

We compared the SMILES $\mathrm{O}_{3}$ VMR profiles (in BandA and Band-B) with SMILES(JAXA) datasets, ozonesonde datasets, five satellite-borne instrument datasets, and one balloon-borne instrument dataset. The overall profiles of the 


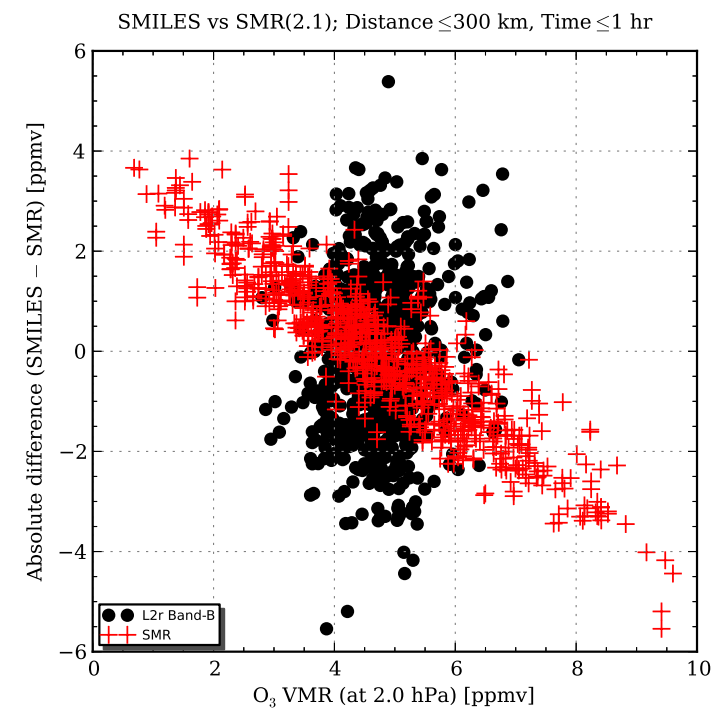

Fig. 21. Measured $\mathrm{O}_{3}$ abundances of SMILES and SMR, and corresponding absolute differences. Only Band-B data for SMILES is shown.
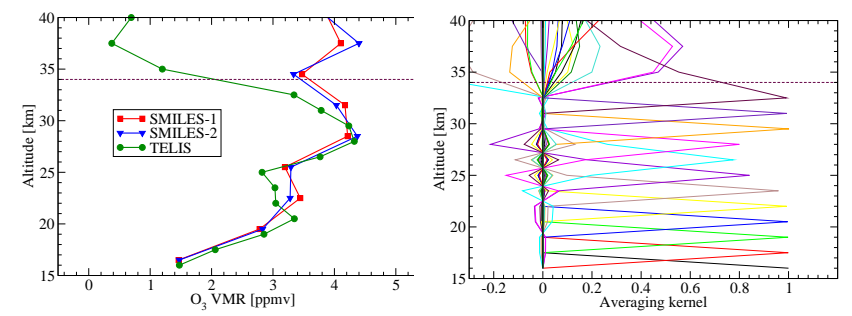

Fig. 22. Left panel: comparison of ozone retrieval between SMILES and TELIS on 24 January 2010. The dashed horizontal maroon line indicates the observing altitude of TELIS. The geolocation information is: $63^{\circ} \mathrm{N}, 24^{\circ} \mathrm{E}$ for SMILES- $1,64^{\circ} \mathrm{N}, 31^{\circ} \mathrm{E}$ for SMILES2 , and $66^{\circ} \mathrm{N}, 27^{\circ} \mathrm{E}$ for TELIS. The time difference of the SMILES and TELIS measurements was about $0.5 \mathrm{~h}$. Right panel: the corresponding averaging kernels for the TELIS retrieval.

absolute and relative differences are shown in Figs. 23 and 24 for Band-A and Band-B, respectively. Absolute and relative differences were calculated by Eqs. (2) and (3), respectively. Total systematic error, from the error analysis in Sect. 2.3, is shown as the dark gray region.

There is a clear difference between SMILES $\mathrm{O}_{3}$ in Band$A$ and Band-B as shown in Sect. 3. The result of validation with ozonesonde clearly shows that Band-B has better performance in the $60-6 \mathrm{hPa}(18-32 \mathrm{~km})$ region. This fact suggests that the nonlinearity correction on the radiance calibration of Band-B is better than that of Band-A. The difference between ozonesondes and SMILES $\mathrm{O}_{3}$ in Band-B is less than $3 \%(0.1 \mathrm{ppm})$ in the $60-6 \mathrm{hPa}(18-32 \mathrm{~km})$ region. The $\mathrm{O}_{3}$ SMILES v2.1.5 of Band-B is better than that of Band-A for the absolute values of the scientific discussion.

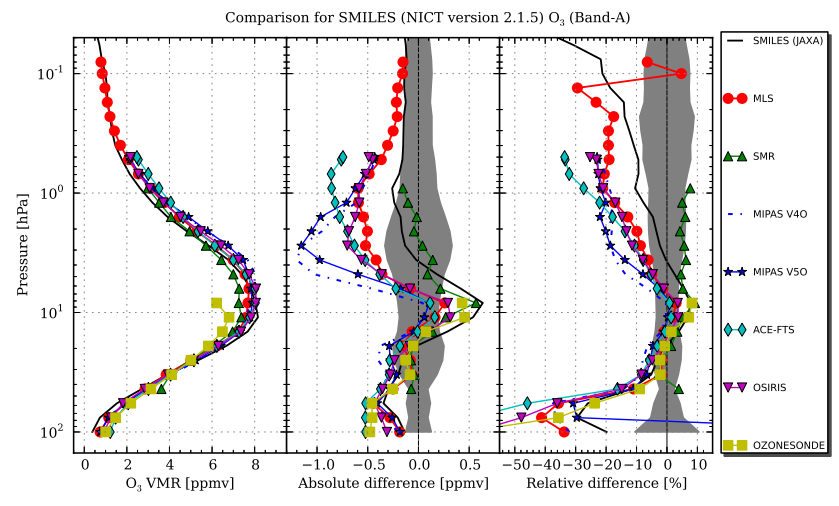

Fig. 23. Synthesis plots for $\mathrm{O}_{3}$ profiles (left panel), mean absolute differences (middle panel) and mean relative differences (right panel) of profile comparisons. Each line shows global comparison between SMILES Band-A and another instrument. Dark gray zone indicates the systematic error of SMILES discussed in Sect. 2.3.

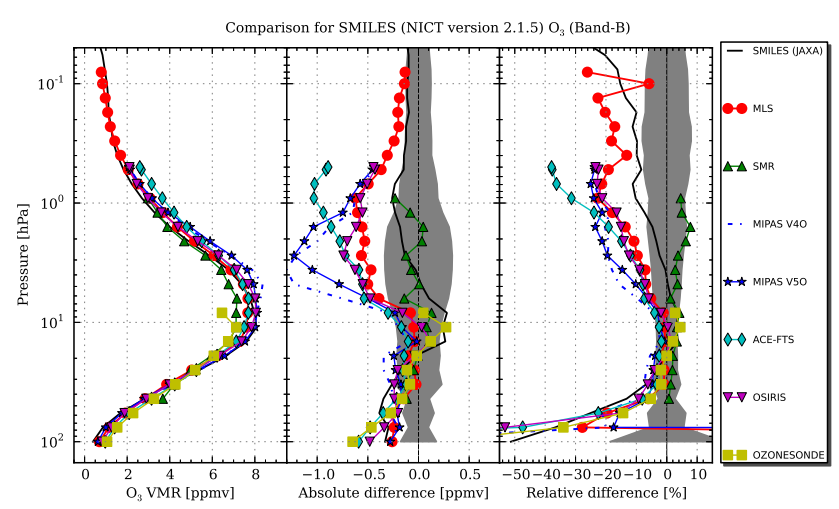

Fig. 24. Same as in Fig. 23, but for the SMILES Band-B comparisons.

From here, we discuss mainly SMILES Band-B $\mathrm{O}_{3}$. These SMILES $\mathrm{O}_{3}$ profiles agreed well with other measurements in the altitude region $50-8 \mathrm{hPa}$ to within about $10 \%$ and 0.5 ppmv as shown in Fig. 24. However, SMILES $\mathrm{O}_{3}$ is lower than other measurements at pressure less than $6 \mathrm{hPa}$ $(32 \mathrm{~km})$. The differences between the other satellite observations are about 10-30\% and increase with height. Although it was known that the MIPAS $\mathrm{O}_{3}$ profiles have positive biases (+0.9 ppmv at a maximum) around $37 \mathrm{~km}$ (Stiller et al., 2012), the $\mathrm{SMR} \mathrm{O}_{3}$ dataset has about 5 to $7 \%$ negative biases between $\sim 20$ and $\sim 40 \mathrm{~km}$ (Jones et al., 2007), and ACEFTS has a small positive bias left (private communication after Dupuy et al., 2009), SMILES O 3 was absolutely lower than all other measurements above $6 \mathrm{hPa}(32 \mathrm{~km})$. This negative bias above $6 \mathrm{hPa}(32 \mathrm{~km})$ mainly arises from the tangent height determination problem, which mostly originated in the uncertainties in the nonlinearity gain calibration. Uncertainties in the spectroscopic parameters and the response function of the AOS spectrometer also affect the errors in the $\mathrm{O}_{3}$ retrieval as described in Sect. 2.3. These uncertainties 


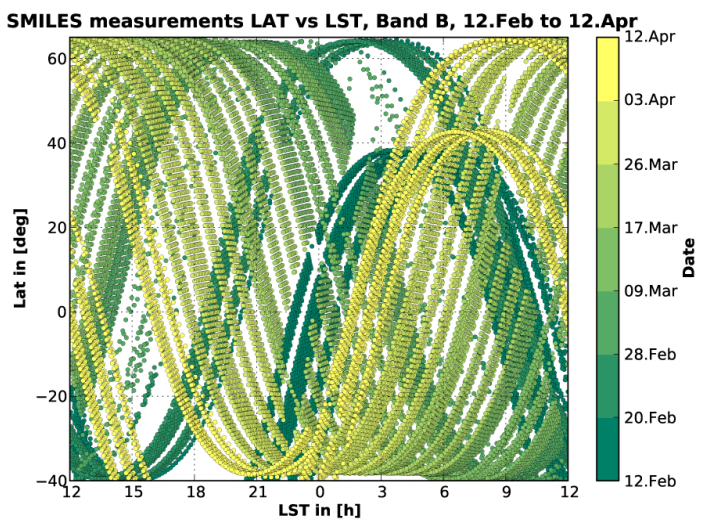

Fig. 25. SMILES measurement locations plotted with respect to latitude and local solar time (LST) over a two month period. The coloring indicates the date when a profile was measured.

of the spectral calibration, tangent height, and instrumental function of the spectrometer are planned to be improved in the $\mathrm{L} 1 \mathrm{~b}$ version 008 spectra.

In summary, the absolute value of the SMILES Band- $\mathrm{B} \mathrm{O}_{3}$ profile is scientifically useful in the altitude range between 60 and $6 \mathrm{hPa}(18-32 \mathrm{~km})$. Above $6 \mathrm{hPa}(32 \mathrm{~km})$, the precision is good enough but the absolute value might be 10-30\% lower than the true value.

\section{SMILES $_{3}$ diurnal variation}

Figure 25 shows SMILES $\mathrm{O}_{3}$ observation locations on a latitude vs. local solar time (LST) grid between 12 February and 12 April 2010. The latitude range is limited to the equatorial region $\left(20^{\circ} \mathrm{S}-20^{\circ} \mathrm{N}\right)$. The colors indicate the date in the two month period when each measurement was taken. A period of approximately two months is needed to obtain a homogeneous sampling of data at each geolocation for $24 \mathrm{~h}$. We can see two problems from Fig. 25, where (1) the data sampling is not completely homogeneously distributed, and (2) the two-month period brings dynamical, seasonal, and latitudinal variations, particularly to stratospheric ozone.

The diurnal variation of $\mathrm{O}_{3}$ from SMILES Band-B is shown in Fig. 26 for the stratosphere and mesosphere for the same period as Fig. $25\left(20^{\circ} \mathrm{S}-20^{\circ} \mathrm{N}\right)$. The SMILES profiles were binned into one-hour bins by LST as well as $1^{\circ}$ latitude bins and then averaged, since the number of the observations in one bin is not the same. As in Fig. 25 the LST is shifted to place midnight in the center of the $\mathrm{x}$-axis. Throughout the day the stratospheric $\mathrm{O}_{3}$ layer is continuous, showing no significant variation with LST. The inhomogeneous sampling of the atmospheric composition is clearly shown.

Above $0.5 \mathrm{hPa}$, in the mesosphere, SMILES observes increasing $\mathrm{O}_{3}$ concentrations during the night. Reaching as high as $90 \mathrm{~km}$, the secondary mesospheric $\mathrm{O}_{3}$ maximum is clearly shown. At $0.001 \mathrm{hPa}$, the peak maximum of

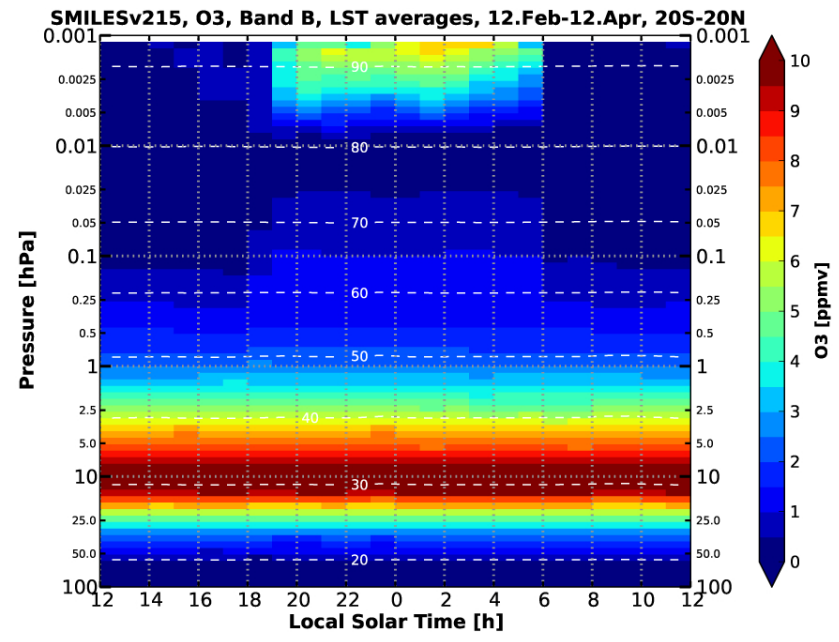

Fig. 26. Diurnal variation of $\mathrm{O}_{3} \mathrm{VMR}$ in ppmv in the stratosphere and mesosphere are shown for the equatorial region $20^{\circ} \mathrm{S}-20^{\circ} \mathrm{N}$. The SMILES profiles are binned to $1 \mathrm{~h}$ LST bins and plotted vertically against pressure.

$\mathrm{O}_{3}$ reached to $6.5 \mathrm{ppmv}$ between 01:00 and 04:00 LST At $0.01 \mathrm{hPa}$ the systematic error is about $0.2 \mathrm{ppmv}$. The mesospheric diurnal variation of $\mathrm{O}_{3}$ was significantly larger than error amount.

\section{Conclusions}

We performed observations of the ozone $\left(\mathrm{O}_{3}\right)$ in the height region of $250-0.0005 \mathrm{hPa}$ at various local times using the $\mathrm{Su}-$ perconducting Submillimeter-Wave Limb-Emission Sounder on the Japanese Experiment Module on the International Space Station between 12 October 2009 and 21 April 2010. SMILES performed the $\mathrm{O}_{3}$ spectral observations at $625.371 \mathrm{GHz}$ with one order of magnitude better signal-tonoise ratios than past space-based microwave instruments due to the use of new $4 \mathrm{~K}$ heterodyne receiver technology. The SMILES $\mathrm{O}_{3}$ product (NICT L2 version 2.1.5) processed from the Band-A and Band-B measurements used the calibrated spectra, L1b version 007.

We assessed the SMILES $\mathrm{O}_{3}$ product version 2.1 .5 by error analysis, internal comparisons between three different instrumental setups for the $\mathrm{O}_{3} 625.371 \mathrm{GHz}$ transition, comparison between the two different algorithms for the same SMILES $\mathrm{O}_{3}$ observation, and comparison with ozonesondes, with other satellite observations by ENVISAT/MIPAS, SCISAT/ACE-FTS, Odin/OSIRIS, Odin/SMR, and Aura/MLS for various local times, and with TELIS balloon observations.

Error analysis: the results of the error analysis for SMILES v2.1.5 showed that the altitude sensitivity of the single scan measurement ranges from $\sim 16$ to $\sim 90 \mathrm{~km}(\sim$ $100-0.001 \mathrm{hPa}$ ) with a vertical resolution of $3-10 \mathrm{~km}$. The retrieval error due to the measurement noise is very low, 
smaller than $1 \%$ of the retrieved $\mathrm{O}_{3}$ VMRs, at $\sim 20-50 \mathrm{~km}$ $(40-1 \mathrm{hPa})$. The systematic error is estimated to be about $3-$ $8 \%$ in the stratosphere and increases to $10 \%$ in the mesosphere. In the mesosphere the spectral noise becomes a more dominant error source than the model parameters, which implies that averaging of the profiles is required to have a better signal-to-noise ratio.

SMILES internal comparisons: a comparison of the different instrumental setups for the $625.371 \mathrm{GHz} \mathrm{\textrm {O } _ { 3 }}$ observation was performed. It was clearly shown that SMILES $\mathrm{O}_{3}$ has different performance in the Band-A and Band-B. The reason is that there is a calibration nonlinearity problem left in the L1b spectrum. This affects especially lower stratospheric $\mathrm{O}_{3}$. This problem is still under the investigation in the $\mathrm{L} 1 \mathrm{~b}$ version 008.

The consistency check between the two different retrieval processings showed a better agreement for the $\mathrm{O}_{3}$ profile from Band-B. The inconsistency between Band-A and Band$\mathrm{B} \mathrm{O}_{3}$ is at the maximum $10 \%$ (at $8.3 \mathrm{hPa}$ ) in the equator conditions for December 2009 measurements. For any scientific studies which require uncertainties better than this level, we recommend it is better to use the Band- $\mathrm{B} \mathrm{O}_{3}$ product instead of merging the data from the two bands.

External comparisons: the difference between ozonesonde and SMILES $\mathrm{O}_{3}$ vertical profiles was within $\pm 8 \%$ at 40 $8 \mathrm{hPa}$, showing a better agreement for the $\mathrm{O}_{3}$ retrieved from Band-B than that from Band-A. SMILES $\mathrm{O}_{3}$ also agreed well with satellite measurements to within $10 \%$ below $6 \mathrm{hPa}$ (32 km). SMILES $\mathrm{O}_{3}$ was $10-20 \%$ smaller than all other satellite measurements above $6 \mathrm{hPa}$. This negative bias becomes larger with altitude, and can be explained by the error from retrieved tangent height. We retrieve the tangent heights from ozone spectrum, and the origin of error is presumably coming from the uncertainty of the gain calibration of L1b spectrum.

The next version of L1b data (version 008) will include an improvement in the gain calibration. The NICT SMILES data processing team will use the new calibrated measurements, L1b 008, for the new L2 data processing, L2 v3.0.0. We confirm that the negative bias of $\mathrm{O}_{3}$ at upper altitude profiles had been certainly improved from the preliminary analysis. Also the improvement of the quality of retrievals in the upper troposphere and lower stratosphere (not only $\mathrm{O}_{3}$ but also humidity and ice cloud) is also considered in this new L2 processing by using a wider bandwidth of the measurement spectra.

Summary of the validation of SMILES v2.1.5 $\mathrm{O}_{3}$ : SMILES $\mathrm{v} 2.1 .5 \mathrm{O}_{3}$ data are scientifically useful over the range 60 to $8 \mathrm{hPa}$ with an accuracy of better than $0.3 \mathrm{ppmv}$ with vertical resolution of 3-4 km. The random error for a single measurement is kept lower than the estimated systematic errors at stratosphere, being $\sim 1 \%$ in the $40-1 \mathrm{hPa}$ pressure region. We recommend the use of the SMILES $\mathrm{O}_{3}$ values for pressures less than $6 \mathrm{hPa}$ only for the variation discussion and no absolute value discussion because of the negative bias (10$30 \%)$ in this region.

Diurnal variation of $\mathrm{O}_{3}$ in the stratosphere and mesosphere: an example of the diurnal variation of stratospheric and mesospheric $\mathrm{O}_{3}$ vertical profiles $(100-0.001 \mathrm{hPa})$ for SMILES v2.1.5 was shown for the SMILES observation period. SMILES observations have unique sampling patterns, which should be carefully considered in the discussion of the diurnal variation.

SMILES v2.1.5 products are available to users from the website, http://smiles.nict.go.jp/pub/data/index.html.

Acknowledgements. Data processing was performed with the NICT Science Cloud at National Institute of Information and Communications Technology (NICT) as a collaborative research project. The authors wish to acknowledge the contributions made by our colleagues at JAXA and NICT for managing and supporting the SMILES mission. We would like to thank K. Muranaga and T. Haru from Systems Engineering Consultants Co. LTD. and J. Möller from Molflow Ltd. Co. for their contribution to the development of the SMILES data processing system at NICT. The author YK appreciates T. Tanaka and K. Kita (Ibaraki Univ.) for their supports and valuable discussion of the validation study. YK thanks to Takatoshi Sakazaki for the discussion of the diurnal variation of ozone. YK also appreciates valuable information and comments from C. Mitsuda (Fujitsu F. I. P.) for the comparison of the NICT and JAXA products. The Atmospheric Chemistry Experiment (ACE), also known as SCISAT, is a Canadian-led mission mainly supported by the Canadian Space Agency (CSA) and the Natural Sciences and Engineering Research Council of Canada (NSERC). We thank the ACE-FTS team for providing us with the ACE-FTS validation tools. Odin is a Swedish-led satellite project funded jointly by the Swedish National Space Board (SNSB), the CSA, the Centre National d'Études Spatiales (CNES) in France, the National Technology Agency of Finland (Tekes) and the European Space Agency (ESA). We thank World Ozone and Ultraviolet Data Center (WOUDC) and its data originators for ozonesonde measurements. We also thank A. M. Thompson (the SHADOZ project principal investigator) and the SHADOZ station principal investigators for allowing us to use their data in this study. We thank the Aura-MLS Data Distribution Team and the Aura Validation Data Center (AVDC) for use of the Aura-MLS Level 2 data made at the Jet Propulsion Laboratory (JPL) and California Institute of Technology (CalTech). Work at the Jet Propulsion Laboratory, California Institute of Technology was carried out under contract with the National Aeronautics and Space Administration. The TELIS team at DLR would like to thank Gerald Wetzel and Hermann Oelhaf for providing temperature profiles from the MIPAS-B retrievals. YK is supported by a Funding Program for Next Generation World-Leading Researchers (NEXT Program) (No. GR101). TOS is supported by a Grant in Aid for Research Fellowship for Young Scientists DC1 (No. 23-9766) from the Japan Society for the Promotion of Science.

Edited by: R. Eckman 


\section{References}

Baron, P., Urban, J., Sagawa, H., Möller, J., Murtagh, D. P., Mendrok, J., Dupuy, E., Sato, T. O., Ochiai, S., Suzuki, K., Manabe, T., Nishibori, T., Kikuchi, K., Sato, R., Takayanagi, M., Murayama, Y., Shiotani, M., and Kasai, Y.: The Level 2 research product algorithms for the Superconducting Submillimeter-Wave Limb-Emission Sounder (SMILES), Atmos. Meas. Tech., 4, 2105-2124, doi:10.5194/amt-4-2105-2011, 2011.

Bernath, P. F., McElroy, C. T., Abrams, M. C., Boone, C. D., Butler, M., Camy-Peyret, C., Carleer, M., Clerbaux, C., Coheur, P.-F., Colin, R., DeCola, P., DeMazière, M., Drummond, J. R., Dufour, D., Evans, W. F. J., Fast, H., Fussen, D., Gilbert, K., Jennings, D. E., Llewellyn, E. J., Lowe, R. P., Mahieu, E., McConnell, J. C., McHugh, M., McLeod, S. D., Michaud, R., Midwinter, C., Nassar, R., Nichitiu, F., Nowlan, C., Rinsland, C. P., Rochon, Y. J., Rowlands, N., Semeniuk, K., Simon, P., Skelton, R., Sloan, J. J., Soucy, M.-A., Strong, K., Tremblay, P., Turnbull, D., Walker, K. A., Walkty, I., Wardle, D. A., Wehrle, V., Zander, R., and Zou, J.: Atmospheric Chemistry Experiment (ACE): Mission overview, Geophys. Res. Lett., 32, L15S01, doi:10.1029/2005GL022386, 2005.

Boissoles, J., Boulet, C., Tipping, R. H., Brown, A., and Ma, Q.: Theoretical calculation of the translation-rotation collisioninduced absorption in $\mathrm{N}_{2}-\mathrm{N}_{2}, \mathrm{O}_{2}-\mathrm{O}_{2}$, and $\mathrm{N}_{2}-\mathrm{O}_{2}$ pairs, J. Quant. Spectrosc. Ra., 82, 505-516, doi:10.1016/S00224073(03)00174-2, 2003.

Boone, C. D., Nassar, R., Walker, K. A., Rochon, Y., McLeod, S. D., Rinsland, C. P., and Bernath, P. F.: Retrievals for the atmospheric chemistry experiment Fourier-transform spectrometer, Appl. Optics, 44, 7218-7231, doi:10.1364/AO.44.007218, 2005.

Bourassa, A. E., Degenstein, D. A., and Llewellyn, E. J.: SASKTRAN: A spherical geometry radiative transfer code for efficient estimation of limb scattered sunlight, J. Quant. Spectrosc. Ra., 109, 52-73, doi:10.1016/j.jqsrt.2007.07.007, 2007.

Brewer, A. W. and Milford, J. R.: The Oxford-Kew ozone sonde, P. Roy. Soc. Lond. A, 256, 470-495, doi:10.1098/rspa.1960.0120, 1960.

Chauhan, S., Höpfner, M., Stiller, G. P., von Clarmann, T., Funke, B., Glatthor, N., Grabowski, U., Linden, A., Kellmann, S., Milz, M., Steck, T., Fischer, H., Froidevaux, L., Lambert, A., Santee, M. L., Schwartz, M., Read, W. G., and Livesey, N. J.: MIPAS reduced spectral resolution UTLS-1 mode measurements of temperature, $\mathrm{O}_{3}, \mathrm{HNO}_{3}, \mathrm{~N}_{2} \mathrm{O}, \mathrm{H}_{2} \mathrm{O}$ and relative humidity over ice: retrievals and comparison to MLS, Atmos. Meas. Tech., 2, 337353, doi:10.5194/amt-2-337-2009, 2009.

Cortesi, U., Lambert, J. C., De Clercq, C., Bianchini, G., Blumenstock, T., Bracher, A., Castelli, E., Catoire, V., Chance, K. V., De Mazière, M., Demoulin, P., Godin-Beekmann, S., Jones, N., Jucks, K., Keim, C., Kerzenmacher, T., Kuellmann, H., Kuttippurath, J., Iarlori, M., Liu, G. Y., Liu, Y., McDermid, I. S., Meijer, Y. J., Mencaraglia, F., Mikuteit, S., Oelhaf, H., Piccolo, C., Pirre, M., Raspollini, P., Ravegnani, F., Reburn, W. J., Redaelli, G., Remedios, J. J., Sembhi, H., Smale, D., Steck, T., Taddei, A., Varotsos, C., Vigouroux, C., Waterfall, A., Wetzel, G., and Wood, S.: Geophysical validation of MIPAS-ENVISAT operational ozone data, Atmos. Chem. Phys., 7, 4807-4867, doi:10.5194/acp-7-4807-2007, 2007.

Degenstein, D. A., Bourassa, A. E., Roth, C. Z., and Llewellyn, E. J.: Limb scatter ozone retrieval from 10 to $60 \mathrm{~km}$ using a multiplicative algebraic reconstruction technique, Atmos. Chem. Phys., 9, 6521-6529, doi:10.5194/acp-9-6521-2009, 2009.

de Lange, G., Birk, M., Boersma, D., Derckson, J., Dmitriev, P., Ermakov, A., Filippenko, L., Golstein, H., Hoogeveen, R., de Jong, L., Khudchenko, A., Kinev, N., Kiselev, O., van Kuik, B., de Lange, A., van Rantwijk, J., Selig, A., Sobolev, A., Torgashin, M., de Vries, E., Wagner, G., Yagoubov, P., and Koshelets, V.: Development and characterization of the superconducting integrated receiver channel of the TELIS atmospheric sounder, Supercond. Sci. Technol., 23, 045016, doi:10.1088/0953-2048/23/4/045016, 2010.

Dupuy, E., Walker, K. A., Kar, J., Boone, C. D., McElroy, C. T., Bernath, P. F., Drummond, J. R., Skelton, R., McLeod, S. D., Hughes, R. C., Nowlan, C. R., Dufour, D. G., Zou, J., Nichitiu, F., Strong, K., Baron, P., Bevilacqua, R. M., Blumenstock, T., Bodeker, G. E., Borsdorff, T., Bourassa, A. E., Bovensmann, H., Boyd, I. S., Bracher, A., Brogniez, C., Burrows, J. P., Catoire, V., Ceccherini, S., Chabrillat, S., Christensen, T., Coffey, M. T., Cortesi, U., Davies, J., De Clercq, C., Degenstein, D. A., De Mazière, M., Demoulin, P., Dodion, J., Firanski, B., Fischer, H., Forbes, G., Froidevaux, L., Fussen, D., Gerard, P., GodinBeekmann, S., Goutail, F., Granville, J., Griffith, D., Haley, C. S., Hannigan, J. W., Höpfner, M., Jin, J. J., Jones, A., Jones, N. B., Jucks, K., Kagawa, A., Kasai, Y., Kerzenmacher, T. E., Kleinböhl, A., Klekociuk, A. R., Kramer, I., Küllmann, H., Kuttippurath, J., Kyrölä, E., Lambert, J.-C., Livesey, N. J., Llewellyn, E. J., Lloyd, N. D., Mahieu, E., Manney, G. L., Marshall, B. T., McConnell, J. C., McCormick, M. P., McDermid, I. S., McHugh, M., McLinden, C. A., Mellqvist, J., Mizutani, K., Murayama, Y., Murtagh, D. P., Oelhaf, H., Parrish, A., Petelina, S. V., Piccolo, C., Pommereau, J.-P., Randall, C. E., Robert, C., Roth, C., Schneider, M., Senten, C., Steck, T., Strandberg, A., Strawbridge, K. B., Sussmann, R., Swart, D. P. J., Tarasick, D. W., Taylor, J. R., Tétard, C., Thomason, L. W., Thompson, A. M., Tully, M. B., Urban, J., Vanhellemont, F., Vigouroux, C., von Clarmann, T., von der Gathen, P., von Savigny, C., Waters, J. W., Witte, J. C., Wolff, M., and Zawodny, J. M.: Validation of ozone measurements from the Atmospheric Chemistry Experiment (ACE), Atmos. Chem. Phys., 9, 287-343, doi:10.5194/acp-9-287-2009, 2009.

Fischer, H., Birk, M., Blom, C., Carli, B., Carlotti, M., von Clarmann, T., Delbouille, L., Dudhia, A., Ehhalt, D., Endemann, M., Flaud, J. M., Gessner, R., Kleinert, A., Koopman, R., Langen, J., López-Puertas, M., Mosner, P., Nett, H., Oelhaf, H., Perron, G., Remedios, J., Ridolfi, M., Stiller, G., and Zander, R.: MIPAS: an instrument for atmospheric and climate research, Atmos. Chem. Phys., 8, 2151-2188, doi:10.5194/acp-8-2151-2008, 2008.

Froidevaux, L., Jiang, Y. B., Lambert, A., Livesey, N. J., Read, W. G., Waters, J. W., Browell, E. V., Hair, J. W., Avery, M. A., McGee, T. J., Twigg, L. W., Sumnicht, G. K., Jucks, K. W., Margitan, J. J., Sen, B., Stachnik, R. A., Toon, G. C., Bernath, P. F., Boone, C. D., Walker, K. A., Filipiak, M. J., Harwood, R. S., Fuller, R. A., Manney, G. L., Schwartz, M. J., Daffer, W. H., Drouin, B. J., Cofield, R. E., Cuddy, D. T., Jarnot, R. F., Knosp, B. W., Perun, V. S., Snyder, W. V., Stek, P. C., Thurstans, R. P., and Wagner, P. A.: Validation of aura microwave limb sounder stratospheric ozone measurements, J. Geophys. Res., 113, D15S20, doi:10.1029/2007JD008771, 2008. 
Harris, N., Hudson, R., and Phillips, C.: SPARC/IOC/GAW Assessment of Trends in the Vertical Distribution of Ozone, Tech. rep., SPARC report No. 1, WMO Global Ozone Research and Monitoring Project Report No. 43, Geneva, 1998.

Jégou, F., Urban, J., de La Noë, J., Ricaud, P., Le Flochmoën, E., Murtagh, D. P., Eriksson, P., Jones, A., Petelina, S., Llewellyn, E. J., Lloyd, N. D., Haley, C., Lumpe, J., Randall, C., Bevilacqua, R. M., Catoire, V., Huret, N., Berthet, G., Renard, J. B., Strong, K., Davies, J., Mc Elroy, C. T., Goutail, F., and Pommereau, J. P.: Technical Note: Validation of Odin/SMR limb observations of ozone, comparisons with OSIRIS, POAM III, ground-based and balloon-borne instruments, Atmos. Chem. Phys., 8, 3385-3409, doi:10.5194/acp-8-3385-2008, 2008.

JEM/SMILES Mission Plan: JEM/SMILES Mission Plan, ver. 2.1, Tech. rep., NASDA and NICT, available at: http://www2.nict.go.jp/y/y222/SMILES/Mission_Plan/version2. 1/SMILES_MP_ver2.11.pdf (last access: 12 March 2013), 2002.

Jiang, J. H., Froidevaux, L., Lambert, A., Livesey, N. J., Read, W. G., Waters, J. W., Bojkov, B., Leblanc, T., McDermid, I., Godin-Beekmann, S., Filipiak, M., Harwood, R., Fuller, R. A., Daffer, W. H., Drouin, B. J., Cofield, R. E., Cuddy, D. T., Jarnot, R. F., Knosp, B. W., Perun, V. S., Schwartz, M. J., Snyder, W. V., Stek, P. C., Thurstans, R. P., Wagner, P. A., Allaart, M., Andersen, S. B., Bodeker, G., Calpini, B., Claude, H., Coetzee, G., Davies, J., De Backer, H., Dier, H., Fujiwara, M., Johnson, B., Kelder, H., Leme, N. P., Konig-Langlo, G., Kyro, E., Laneve, G., Fook, L. S., Merrill, J., Morris, G., Newchurch, M., Oltmans, S., Parrondos, M. C., Posny, F., Schmidlin, F., Skrivankova, P., Stubi, R., Tarasick, D., Thompson, A., Thouret, V., Viatte, P., Vomel, H., von der Gathen, P., Yela, M., and Zablocki, G.: Validation of the aura microwave limb sounder ozone by ozonesonde and lidar measurements, J. Geophys. Res., 112, D24S34, doi:10.1029/2007JD008776, 2007.

Jones, A., Murtagh, D., Urban, J., Eriksson, P., and Rösevall, J.: Intercomparison of Odin/SMR ozone measurements with MIPAS and balloonsonde data, Can. J. Phys., 85, 1111-1123, doi:10.1139/P07-118, 2007.

Kasai, Y., Urban, J., Takahashi, C., Hoshino, S., Takahashi, K., Inatani, J., Shiotani, M., and Masuko, H.: Stratospheric ozone isotope enrichment studied by submillimeter wave heterodyne radiometry: the observation capabilities of SMILES, IEEE T. Geosci. Remote, 44, 676-693, 2006.

Kerr, J. B., Fast, H., McElroy, C. T., Oltmans, S. J., Lathrop, J. A., Kyro, E., Paukkunen, A., Claude, H., Köhler, U., Sreedharan, C. R., Takao, T., and Tsukagoshi, Y.: The 1991 WMO international ozonesonde intercomparison at Vanscoy, Canada, Atmos. Ocean, 32, 685-715, 1994.

Kikuchi, K.-I., Nishibori, T., Ochiai, S., Ozeki, H., Irimajiri, Y., Kasai, Y., Koike, M., Manabe, T., Mizukoshi, K., Murayama, Y., Nagahama, T., Sano, T., Sato, R., Seta, M., Takahashi, C., Takayanagi, M., Masuko, H., Inatani, J., Suzuki, M., and Shiotani, M.: Overview and early results of the Superconducting Submillimeter-Wave Limb-Emission Sounder (SMILES), J. Geophys. Res., 115, D23306, doi:10.1029/2010JD014379, 2010.

Kobayashi, J. and Toyama, Y.: On various methods of measuring the vertical distribution of atmospheric ozone (III) - carbon-iodine type chemical ozonesonde, Pap. Met. Geophys., 17, 113-126, 1966.
Komhyr, W. D., Barnes, R. A., Brothers, G. B., Lathrop, J. A., and Opperman, D. P.: Electrochemical concentration cell ozonesonde performance evaluation during STOIC 1989, J. Geophys. Res., 100, 9231-9244, doi:10.1029/94JD02175, 1995.

Laeng, A., Grabowski, U., von Clarmann, T., Stiller, G., Kellmann, S., Kiefer, M., Linden, A., Lossow, S., Bathgate, T., Bernath, P., Boone, C. D., Clerbaux, C., Degenstein, D., Fritz, S., Froidevaux, L., Hervig, M., Hoppel, K., Lumpe, J., McHugh, M., Sano, T., Sofieva, V., Suzuki, M., Tamminen, T., Urban, J., Walker, K., Weber, M., and Zawodny, J.: Validation of MIPAS IMK/IAA ozone profiles, Quadrennial Ozone Symposium, Toronto, 2012.

Liebe, H. J., Hufford, G. A., and Cotton, M. G. (Eds.): Propagation modeling of moist air and suspended water/ice particles at frequencies below $1000 \mathrm{GHz}$, 52nd Specialists Meeting of the Electromagnetic Wave Propagation Panel, Palma De Mallorca, Spain, 1993.

Livesey, N. J., van Snyder, W., Read, W. G., and Wagner, P. A.: Retrieval Algorithms for the EOS Microwave Limb Sounder (MLS), IEEE T. Geosci. Remote, 44, 1144-1155, doi:10.1109/TGRS.2006.872327, 2006.

Livesey, N. J., Filipiak, M. J., Froidevaux, L., Read, W. G., Lambert, A., Santee, M. L., Jiang, J. H., Pumphrey, H. C., Waters, J. W., Cofield, R. E., Cuddy, D. T., Daffer, W. H., Drouin, B. J., Fuller, R. A., Jarnot, R. F., Jiang, Y. B., Knosp, B. W., Li, Q. B., Perun, V. S., Schwartz, M. J., Snyder, W. V., Stek, P. C., Thurstans, R. P., Wagner, P. A., Avery, P., Browell, E. V., Cammas, J.-P., Christensen, L. E., Diskin, G. S., Gao, R.-S., Jost, H.-J., Loewenstein, M., Lopez, J. D., Nedelec, P., Osterman, G. B., Sachse, G. W., and Webster, C. R.: Validation of Aura Microwave Limb Sounder $\mathrm{O}_{3}$ and $\mathrm{CO}$ observations in the upper troposphere and lower stratosphere, J. Geophys. Res., 113, D15S02, doi:10.1029/2007JD008805, 2008.

Livesey, J. N., Read, W. G., Froidevaux, L., Lambert, A., Manney, G. L., Pumphrey, H. C., Santee, M. L., Schwartz, M. J., Wang, S., Cofield, R. E., Cuddy, D. T., Fuller, R. A., Jarnot, R. F., Jiang, J. H., Knosp, B. W., Stek, P. C., Wagner, P. A., and $\mathrm{Wu}, \mathrm{D}$. L.: Version 3.3 Level 2 data quality and description document, Tech. Rep., available at: http://mls.jpl.nasa.gov/ data/datadocs.php, last access: 12 March 2013, JPL - Jet Propulsion Laboratory, Pasadena, 2011.

Llewellyn, E., Lloyd, N. D., Degenstein, D. A., Gattinger, R. L., Petelina, S. V., Bourassa, A. E., Wiensz, J. T., Ivanov, E. V., McDade, I. C., Solheim, B. H., McConnell, J. C., Haley, C. S., von Savigny, C., Sioris, C. E., McLinden, C. A., Griffioen, E., Kaminski, J., Evans, W. F. J., Puckrin, E., Strong, K., Wehrle, V., Hum, R. H., Kendall, D. J. W., Matsushita, J., Murtagh, D. P., Brohede, S., Stegman, J., Witt, G., Barnes, G., Payne, W. F., Piche, L., Smith, K., Warshaw, G., Deslauniers, D. L., Marchand, P., Richardson, E. H., King, R. A., Wevers, I., McCreath, W., Kyrola, E., Oikarinen, L., Leppelmeier, G. W., Auvinen, H., Megie, G., Hauchecorne, A., Lefevre, F., de La Noe, J., Ricaud, P., Frisk, U., Sjoberg, F., von Scheele, F., and Nordh, L.: The OSIRIS instrument on the Odin spacecraft, Can. J. Phys., 82, 411-422, doi:10.1139/p04-005, 2004.

McElroy, C. T., Nowlan, C. R., Drummond, J. R., Bernath, P. F., Barton, D. V., Dufour, D. G., Midwinter, C., Hall, R. B., Ogyu, A., Ullberg, A., Wardle, D. I., Kar, J., Zou, J., Nichitiu, F., Boone, C. D., Walker, K. A., and Rowlands, N.: The ACE-MAESTRO instrument on SCISAT: description, perfor- 
mance, and preliminary results, Appl. Optics, 46, 4341-4356, doi:10.1364/AO.46.004341, 2007.

Melsheimer, C., Verdes, C., Bühler, S., Emde, C., Eriksson, P., Feist, D., Ichizawa, S., John, V., Kasai, Y., Kopp, G., Koulev, N., Kuhn, T., Lemke, O., Ochiai, S., Schreier, F., Sreerekha, T., Suzuki, M., Takahashi, C., Tsujimaru, S., and Urban, J.: Intercomparison of General Purpose Clear Sky Atmospheric Radiative Transfer Models for the Millimeter/Submillimeter Spectral Range, Radio Sci., 40, RS1007, doi:10.1029/2004RS003110, 2005.

Merino, F., Murtagh, D. P., Ridal, M., Eriksson, P., Baron, P., Ricaud, P., and de La Noë, J.: Studies for the Odin sub-millimetre radiometer: III. Performance simulations, Can. J. Phys., 80, 357, doi:10.1139/p01-154, 2002.

Mizobuchi, S., Kikuchi, K., Ochiai, S., Nishibori, T., Sano, T., Takami, K., and Ozeki, H.: In-orbit measurement of the AOS (Acousto-Optical Spectrometer) response using frequency comb signals, IEEE J. Sel. Topics Appl. Earth Obs. Remote Sens., 5, 977-983, 2012.

Murtagh, D., Frisk, U., Merino, F., Ridal, M., Jonsson, A., Stegman, J., Witt, G., Eriksson, P., Jiménez, C., Megie, G., de La Noë, J., Ricaud, P., Baron, P., Pardo, J. R., Hauchcorne, A., Llewellyn, E. J., Degenstein, D. A., Gattinger, R. L., Lloyd, N. D., Evans, W. F. J., McDade, I. C., Haley, C. S., Sioris, C., von Savigny, C., Solheim, B. H., McConnell, J. C., Strong, K., Richardson, E. H., Leppelmeier, G. W., Kyrölä, E., Auvinen, H., and Oikarinen, L.: Review: an overview of the Odin atmospheric mission, Can. J. Phys., 80, 309-319, doi:10.1139/p01-157, 2002.

Ochiai, S., Kikuchi, K., Nishibori, T., Manabe, T., Ozeki, H., Mizobuchi, S., and Irimajiri, Y.: Receiver performance of Superconducting Submillimeter-Wave LimbEmission Sounder (SMILES) on the International Space Station, IEEE Trans. Geosci. Remote Sens., 51, 3791-3802, doi:10.1109/TGRS.2012.2227758, 2013.

Pardo, J. R., Cernicharo, J., and Serabyn, E.: Atmospheric transmission at microwaves (ATM): an improved model for millimeter/submillimeter applications, IEEE T. Antenn. Propag., 49, 1683-1694, doi:10.1109/8.982447, 2001.

Rienecker, M. M., Suarez, M. J., Todling, R., Bacmeister, J., Takacs, L., Liu, H.-C., Gu, W., Sienkiewicz, M., Koster, R. D., Gelaro, R., Stajner, I., and Nielsen, J. E.: The GEOS-5 Data Assimilation System - Documentation of Version 5.0.1, 5.1.0, and 5.2.0., Tech. Rep. NASA/TM-2008-104606, available at: http://mls.jpl. nasa.gov/data/datadocs.php, last access: 12 March 2013, National Aeronautics and Space Administration, Goddared, 2008.

Rodgers, C. D.: Inverse Methods for Atmospheric Sounding: Theory and Practice, Series on Atmospheric, Oceanic and Planetary Physics, 2, World Scientific, London, 2000.

Rothman, L. S., Gordon, I. E., Barbe, A., Benner, D. C., Bernath, P. F., Birk, M., Boudon, V., Brown, L. R., Campargue, A., Champion, J.-P., Chance, K., Coudert, L. H., Dana, V., Devi, V. M., Fally, S., Flaud, J.-M., Gamache, R. R., Goldman, A., Jacquemart, D., Kleiner, I., Lacome, N., Lafferty, W. J., Mandin, J.-Y., Massie, S. T., Mikhailenko, S. N., Miller, C. E., Moazzen-Ahmadi, N., Naumenko, O. V., Nikitin, A. V., Orphal, J., Perevalov, V. I., Perrin, A., Predoi-Cross, A., Rinsland, C. P., Rotger, M., Šimečková, M., Smith, M. A. H., Sung, K., Tashkun, S. A., Tennyson, J., Toth, R. A., Vandaele, A. C., and Vander Auwera, J.: The HITRAN 2008 molecular spectroscopic database, J. Quant. Spectrosc. Ra., 110, 533-572, doi:10.1016/j.jqsrt.2009.02.013, 2009.

Sato, T. O., Sagawa, H., Kreyling, D., Manabe, T., Ochiai, S., Kikuchi, K., Baron, P., Mendrok, J., Urban, J., Murtagh, D., Yasui, M., and Kasai, Y.: Strato-mesospheric ClO observations by SMILES: error analysis and diurnal variation, Atmos. Meas. Tech., 5, 2809-2825, doi:10.5194/amt-5-2809-2012, 2012.

Schoeberl, M. R., Douglass, A. R., Hilsenrath, E., Bhartia, P. K., Beer, R., Waters, J. W., Gunson, M. R., Froidevaux, L., Gille, J. C., Barnett, J. J., Levelt, P. F., and de Cola, P.: Overview of the EOS Aura Mission, IEEE T. Geosci. Remote, 44, 1066-1074, doi:10.1109/TGRS.2005.861950, 2006.

Schreier, F. and Schimpf, B.: A new efficient line-by-line code for high resolution atmospheric radiation computations incl. derivatives, in: IRS 2000: Current Problems in Atmospheric Radiation, edited by: Smith, W. and Timofeyev, Y., A. Deepak Publishing, St. Petersberg, Russia, 381-384, 2001.

Smit, H. G. J., Straeter, W., Johnson, B. J., Oltmans, S. J., Davies, J., Tarasick, D. W., Hoegger, B., Stubi, R., Schmidlin, F. J., Northam, T., Thompson, A. M., Witte, J. C., Boyd, I., and Posny, F.: Assessment of the performance of ECC-ozonesondes under quasi-flight conditions in the environmental simulation chamber: insights from the Juelich Ozone Sonde Intercomparison Experiment (JOSIE), J. Geophys. Res., 112, D19306, doi:10.1029/2006JD007308, 2007.

Steck, T. and von Clarmann, T.: Constrained profile retrieval applied to the observation mode of the Michelson Interferometer for Passive Atmospheric Sounding, Appl. Optics, 40, 3559-3571, 2001

Steck, T., von Clarmann, T., Fischer, H., Funke, B., Glatthor, N., Grabowski, U., Höpfner, M., Kellmann, S., Kiefer, M., Linden, A., Milz, M., Stiller, G. P., Wang, D. Y., Allaart, M., Blumenstock, Th., von der Gathen, P., Hansen, G., Hase, F., Hochschild, G., Kopp, G., Kyrö, E., Oelhaf, H., Raffalski, U., Redondas Marrero, A., Remsberg, E., Russell III, J., Stebel, K., Steinbrecht, W., Wetzel, G., Yela, M., and Zhang, G.: Bias determination and precision validation of ozone profiles from MIPAS-Envisat retrieved with the IMK-IAA processor, Atmos. Chem. Phys., 7, 3639-3662, doi:10.5194/acp-7-3639-2007, 2007.

Stiller, G. P., Kiefer, M., Eckert, E., von Clarmann, T., Kellmann, S., García-Comas, M., Funke, B., Leblanc, T., Fetzer, E., Froidevaux, L., Gomez, M., Hall, E., Hurst, D., Jordan, A., Kämpfer, N., Lambert, A., McDermid, I. S., McGee, T., Miloshevich, L., Nedoluha, G., Read, W., Schneider, M., Schwartz, M., Straub, C., Toon, G., Twigg, L. W., Walker, K., and Whiteman, D. N.: Validation of MIPAS IMK/IAA temperature, water vapor, and ozone profiles with MOHAVE-2009 campaign measurements, Atmos. Meas. Tech., 5, 289-320, doi:10.5194/amt-5-289-2012, 2012.

Suttiwong, N., Birk, M., Wagner, G., Krocka, M., Wittkamp, M., Haschberger, P., Vogt, P., and Geiger, F.: Development and characterization of the balloon borne instrument TELIS (TEhertz and Submm LImb Sounder): $1.8 \mathrm{THz}$ receiver, in: Proc. 19th ESA Symposium on European Rocket and Balloon Programmes and Related Research, Bad Reichenhall, Germany, 2009.

Thompson, A. M., Witte, J. C., McPeters, R. D., Oltmans, S. J., Schmidlin, F. J., Logan, J. A., Fujiwara, M., Kirchhoff, V. W. J. H., Posny, F., Coetzee, G. J. R., Hoegger, B., Kawakami, S., Ogawa, T., Johnson, B. J., Vömel, H., and Labow, G.: Southern Hemisphere Additional Ozonesondes (SHADOZ) 1998-2000 tropical ozone climatology 1. Comparison with Total Ozone Mapping Spectrometer (TOMS) and 
ground-based measurements, J. Geophys. Res., 108, 8238, doi:10.1029/2001JD000967, 2003.

Urban, J., Lautié, N., Le Flochmoën, E., Jiménez, C., Eriksson, P., de La Noë, J., Dupuy, E., Ekström, M., El Amraoui, L., Frisk, U., Murtagh, D., Olberg, M., and Ricaud, P.: Odin/SMR limb observations of stratospheric trace gases: Level 2 processing of $\mathrm{ClO}, \mathrm{N}_{2} \mathrm{O}, \mathrm{HNO}_{3}$, and $\mathrm{O}_{3}$, J. Geophys. Res., 110, D14307, doi:10.1029/2004JD005741, 2005.

Urban, J., Murtagh, D., Lautié, N., Barret, B., Dupuy, E., de La Noë, J., Eriksson, P., Frisk, U., Jones, A., Le Flochmoën, E., Olberg, M., Piccolo, C., Ricaud, P., and Rösevall, J.: Odin/SMR Limb Observations of Trace Gases in the Polar Lower Stratosphere during 2004-2005, in: Proc. ESA Atmospheric Science Conference, European Space Agency publications ESA-SP-628, ESA, Noordwijk, Holland, 2006.

von Clarmann, T.: Validation of remotely sensed profiles of atmospheric state variables: strategies and terminology, Atmos. Chem. Phys., 6, 4311-4320, doi:10.5194/acp-6-4311-2006, 2006.

von Clarmann, T., Höpfner, M., Funke, B., López-Puertas, M., Dudhia, A., Jay, V., Schreier, F., Ridolfi, M., Ceccherini, S., Kerridge, B., Reburn, J., and Siddans, R.: Modeling of atmospheric mid-infrared radiative transfer: The AMIL2DA algorithm intercomparison experiment, J. Quant. Spectrosc. Ra., 78, 381-407, doi:10.1016/S0022-4073(02)00262-5, 2002.

von Clarmann, T., Höpfner, M., Kellmann, S., Linden, A., Chauhan, S., Funke, B., Grabowski, U., Glatthor, N., Kiefer, M., Schieferdecker, T., Stiller, G. P., and Versick, S.: Retrieval of temperature, $\mathrm{H}_{2} \mathrm{O}, \mathrm{O}_{3}, \mathrm{HNO}_{3}, \mathrm{CH}_{4}, \mathrm{~N}_{2} \mathrm{O}, \mathrm{ClONO}_{2}$ and $\mathrm{ClO}$ from MIPAS reduced resolution nominal mode limb emission measurements, Atmos. Meas. Tech., 2, 159-175, doi:10.5194/amt-2-159-2009, 2009.
Waters, J. W., Froidevaux, L., Harwood, R. S., Jarnot, R. F., Pickett, H. M., Read, W. G., Siegel, P. H., Cofield, R. E., Filipiak, M. J., Flower, D. A., Holden, J. R., Lau, G. K., Livesey, N. J., Manney, G. L., Pumphrey, H. C., Santee, M. L., Wu, D. L., Cuddy, D. T., Lay, R. R., Loo, M. S., Perun, V. S., Schwartz, M. J., Stek, P. C., Thurstans, R. P., Boyles, M. A., Chandra, K. M., Chavez, M. C., Chen, G.-S., Chudasama, B. V., Dodge, R., Fuller, R. A., Girard, M. A., Jiang, J. H., Jiang, Y., Knosp, B. W., Labelle, R. C., Lam, J. C., Lee, A. K., Miller, D., Oswald, J. E., Patel, N. C., Pukala, D. M., Quintero, O., Scaff, D. M., Vansnyder, W., Tope, M. C., Wagner, P. A., and Walch, M. J.: The Earth Observing System Microwave Limb Sounder (EOS MLS) on the Aura Satellite, IEEE T. Geosci. Remote , 44, 1075-1092, doi:10.1109/TGRS.2006.873771, 2006.

Waymark, C., Walker, K. A., Boone, C. D., Dupuy, E., and Bernath, P. F.: Validation of the ACE-FTS Version 3.0 Dataset Against Other Satellite Instrument Datasets, OSA Technical Digest (CD), Optical Society of America, Toronto, Canada, 2011.

Wetzel, G., Oelhaf, H., Kirner, O., Friedl-Vallon, F., Ruhnke, R., Ebersoldt, A., Kleinert, A., Maucher, G., Nordmeyer, H., and Orphal, J.: Diurnal variations of reactive chlorine and nitrogen oxides observed by MIPAS-B inside the January 2010 Arctic vortex, Atmos. Chem. Phys., 12, 6581-6592, doi:10.5194/acp12-6581-2012, 2012.

$\mathrm{Xu}$, J., and Schreier, F., and Vogt, P., and Doicu, A., and Trautmann, T.,: A sensitivity study for far infrared balloon-borne limb emission sounding of stratospheric trace gases: Geoscientific Instrumentation, Methods and Data Systems Discussions, 3, 251-303, 2013. 